POTENTIAL ECOSYSTEM COVER -

\title{
A NEW APPROACH TO CONSERVATION BIOLOGY
}

\section{O. V. Smirnova}

Center for ecological and forest productivity problems, 84/32 Profsoyuznaya street, Moscow, 117810, Russia

E-mail: ovsinfo@gmail.com

\section{N. A. Toropova}

Center for ecological and forest productivity problems, 84/32 Profsoyuznaya street, Moscow, 117810, Russia E-mail: na.toropova@mail.ru

\section{ПОТЕНЦИАЛЬНЫЙ ЭКОСИСТЕМНЫЙ ПОКРОВ - НОВЫЙ ПОДХОД К СОХРАНЕНИЮ ПРИРОДЫ}

\section{О. В. Смирнова}

Центр по проблемам экологии и продуктивности лесов РАН, Россия, 117485, г. Москва, ул. Профсоюзная, 84/32 E-mail: ovsinfo@gmail.com

\section{Н. А. Торопова}

Центр по проблемам экологии и продуктивности лесов РАН, Россия, 117485, г. Москва, ул. Профсоюзная, 84/32 E-mail:na.toropova@mail.ru

\begin{abstract}
The paper suggests a new approach to solving the problems of conservation biology. The design of the approach was stimulated, on the one hand, by the absence of a system of theoretical concepts and adequate methods for nature conservation and restoration and, on the other hand, by the need for adequate estimation of nature preservation in the reserves. The paper analyzes classical ideas about potential vegetation and short comings of this approach for evaluating the state of plant cover and predicting its development. On the basis of a synthesis of modern concepts of synecology: hierarchical continuum, gap mosaic, mosaic cycle concept of ecosystem, natural disturbance, keystone species, ecosystem engineer and population-demographic concept - new notions of "potential ecosystem cover" and "potential ecosystem" are suggested. The paper demonstrates perspectives of using the system of synecological concepts for development of ideas about successions and climax and for model reconstruction of the potential ecosystem cover. General approaches and specifics of reconstructing the potential ecosystem cover of forests and steppes are described.
\end{abstract}

Key words: potential vegetation, potential ecosystem cover, basic concepts of synecology, populationdemographic concept, climax, succession, conservation biology, nature reserves.

For citation: Smirnova O.V. Potential ecosystem cover - a new approach to conservation biology. Russian Journal of Ecosystem Ecology. 2016;1(1). Available from: https://doi.org/10.21685/2500-0578-2016-1-1

Аннотация. В статье предложен новый подход к решению проблем сохранения природы. Необходимость в создании данного подхода была вызвана, с одной стороны, отсутствием системы теоретический концепция и адекватных методов сохранения и восстановления природы и, с другой стороны, необходимостью адекватной оценки мероприятий по сохранению природного состояния в заповедниках. В работе анализируются классические представления о потенциальной растительности и недостатки данного подхода для оценки состояния растительного покрова, а также прогнозы его развития. Основываясь на современных принципах синэкологии: иерархический континуум, мозаика щелей, концепция мозаичного цикла экосистемы, природное воздействие, ключевые виды, экосистемная инженерия и популяционно-демографическая концепция, были предложены новые понятия «потенциального покрова экосистемы» и «потенциальной экосистемы». Статья описывает перспективы использования системы синэкологических концепций для развития преставлений о сукцессиях и климаксе для модельной реконструкции потенциального покрова экосистемы. Также рассматриваются основные подходы и особенности реконструкции потенциального покрова екосистемы лесов и степей.

Ключевые слова: потенциальная растительность, потенциальный экосистемный покров, основные концепции синэкологии, популяционно-демографическая концепция, климакс, сукцессии, охрана природы, заповедники. 


\section{Formation and development of views on potential vegetation}

Today, the world community realizes the depth and intensity of transformation of the biosphere, which has negative consequences for both the Earth biota and the development of the human civilization [1-3]. What is necessary is the next step: reorientation of nature management to solving not only resource but also nature-protection problems. Foundations for such a reorientation should be provided by studies of ecosystems and their complexes least transformed by the man and by model reconstructions of natural ecosystems of various climatic zones.

The modern synecology develops a new methodology and methods of model reconstructions of natural ecosystems. This methodology is based on the potencies and positions of systems. Potencies of a system are properties that manifest themselves in full only at spontaneous (endogenously determined) development under optimal conditions. If such a development is disturbed by external (exogenous in respect to the system) influences and/or its development occurs under non-optimal conditions, the system manifests a part of its properties, which characterizes its positions under those circumstances.

Describing ecosystem development in terms of biota potencies, which are realized under certain conditions, is a convenient model, a kind of "etalon" for evaluating the extent of deviations of ecosystems from their natural path and elucidating the causes of these deviations.

The concept of potential (natural) vegetation (potentielle naturliche Vegetation, $P N V$ ) was introduced by R. Tuxen [4]. It was a natural development of F. Clements's ideas about succession as the process of restoration of a disturbed community and climax as the final stage of this process [5]. Following R. Tuxen, many authors gave their definitions to the notion of "potential vegetation". For example, V. Westhoff and E. van der Maarel [6] defined potential vegetation as "...vegetation that would finally develop in a given habitat, if all human influences on the site and surroundings would stop at once, and if the terminal successional stage would be reached at once...". This definition was accepted by the scientific community, and it remains in use so far. It is used when the maps of potential vegetation are drawn, when the problems of nature management are solved, when the historic habitats of animals and plants are restored etc. [7-12].

An increased interest to the concept of "potential vegetation" at the end of the $20^{\text {th }}-$ beginning of the $21^{\text {st }}$ century was caused by the necessity to make a more detailed representation of the etalon object, which was needed for studying the structural-functional organization and dynamics of the plant cover and for solving the problems of preservation and restoration of natural resources.

In parallel with the use of the term "potential vegetation", researchers try to modify it. To characterize natural objects in more detail and deal with the problems of nature management, they specify the notion with the parameters of soils, local climate, fauna etc. $[9,10,13-16]$. These efforts, however, turn out to be insufficient to solve the problems that researchers face today. Studies on the dynamics of plant cover and history of nature management have shown a little use of the notion for solving theoretical and practical problems [17-20].

In the works on the analysis of PNV [16, 21-25], the causes of low effectiveness or inexpediency of using this notion were indicated as follows.

1. A lack of theoretical concepts that would allow one to make an objective decision about the size of areas for PVN research.

2. Low effectiveness of J. Braun-Blanquet classification in evaluation of community dynamics.

3. Accumulation of data on community dynamics that do not agree with the classical concept of autogenous succession and climax by F. E. Clements and E. P. Odum; the concept that the views about potential vegetation are based upon.

4. Underestimation of the role of animals and representatives of other kingdoms in formation of potential vegetation.

5. A lack of justification when the data on the composition, structure and dynamics of vegetation that were obtained for small areas are extrapolated to large areas. This happens when maps of potential vegetation are drawn and prognoses about vegetation development induced by climate changes are given.

6. Fundamental discrepancies in paleoreconstructions due to different theoretical premises and data incompleteness.

7. Absence of accurately dated, solid and unambiguous estimates of the role of nature management in changes of plant cover and fauna in different periods of the humankind history.

8. Fundamental differences in assessment of contributions of natural and anthropogenic factors to the change of plant cover, soils, climate and hydrological regime at different times and on different scales: from local to global.

Despite these shortcomings, the necessity of using the notion of PVN to solve problems of natural conservation and management is actively discussed $[11,16,26-31]$. Many papers point out that the notion should be preserved as a basis, on which the 
objects analyzed can be compared. This is clearly stated in the critical review by I. Somodi et al., who wrote: "We propose to use the static PNV concept as a baseline, a null model for landscape assessment and in comparisons" [32, p. 590]. The authors, who believe the notion is useful, stress that model reconstructions differ in their likelihood and one should constantly improve methods for comparing the objects analyzed to the model image of potential vegetation formed on the basis of studies of the least disturbed (according to historical and contemporary data) communities.

Sharing the viewpoint of those authors on the necessity to develop model conceptions of etalon natural formations, we believe that further progress in this direction is impeded by the following circumstances.

1. Application of the term "potential" towards the plant cover only is ungrounded. Potential vegetation is a part of an integral formation - the potential ecosystem cover. It is impossible to assess the correspondence of a community to its potential state without evaluation of (a) availability of species of other trophic levels and their effects on vegetation and (b) stability of functioning of all the ecosystem elements. Without studying the ecosystems, one cannot depict a natural image of vegetation, which makes it impossible to solve the problems of nature preservation at the level, acceptable for the humankind survival.

2. One cannot make well-founded prognoses for long-term community dynamics to evaluate the extent of restoration of a disturbed natural (potential, climax) state on the sole basis of Clements' classical concepts [5], which were formulated within the framework of the Clementsian organismic paradigm [33].

According to this paradigm,

- plant cover is discrete; it consists of relatively autonomous communities with distinct borders (an analog of organism);

- succession is a determinate process, at different stages of which different companies of dependent plant species will concordantly and sequentially replace each other following the alteration of dominants or aedificators according to J. Braun-Blauquet and J. Pavillard [34];

- the concept of climax and succession states is developed only for the plant community; these states are not considered as immanent ones for the ecosystem as a whole.

During the early periods of the PNV concept development, potential vegetation was believed to be fully reflected by the climax communities characteristic for the final stage of autogenic successions $[35,36]$. However, following the organismic paradigm in the studies of plant community dy- namics resulted in paradoxic (and erroneous) conclusions. For example, considered as climax were forest communities of initial-intermediate succession stages, when a dense (shadow) crown layer was only at the beginning of its formation by the first generation of late-succession tree species (there was still no stable succession of generations). Such an image of a climax community was shaped on the basis of descriptions of the most well-preserved fragments of Eurasian and North American forests. The documented information about the history of their exploitation has shown, however, that they were formed as a result of centuries-old anthropogenic interventions: burning, cutting, pasturing, litter gathering in forest etc. $[20,37-40]$. The discrepancy between the historical data and the image of a climax community in the organismic paradigm led to rejection of classical views on succession and climax and appearance of versatile studies and various models of community dynamics [17-19].

3. A lack of understanding that one should reconstruct the history of nature management of every analyzed territory at all the stages of anthropogenesis, during which human activity became a factor determining the composition, structure and dynamics of ecosystems and their complexes of different size.

Seclusion of specialists in different areas of science makes it difficult to solve the problems of model reconstruction of natural features of regions at different stages of anthropogenesis on the basis of coordinated botanical, zoological, soil science, paleontological, archeological and historical-archive studies, accompanied by radiocarbon and another kind of dating. This explains the existence - up to now - of paradoxic views on formation of European "climax" forests without involvement of key animal species - despite the fact that paleontological and historical materials indicate their presence everywhere $[20,38,41-43]$.

\section{Formation and development of views on the potential ecosystem cover}

As researchers realize the importance of the new discipline, historical ecology, and begin to apply its concepts for development of synecology $[39,44]$, new terms of "potential ecosystem" and "potential ecosystem cover" come into use.

In the light of the ideas of R. Tuxen [4], we propose to enter into scientific use the concept of "potential ecosystem cover" as a complex of "potential ecosystems" which can appear and persist within the boundaries of the territory analyzed under the mod- 
ern climatic conditions - given that anthropogenical influence is stopped and populations of all the keystone and dependent species are restored.

In this definition, an ecosystem is a structuralfunctional element of the biosphere, which is regarded as a unity of the living and nonliving [45]. The ecosystem consists of the biota and the biotatransformed ecotope [36], with the notion of ecotope including local climate, hydrological regime, type of substrate, relief specifics etc.

The size of a potential ecosystem can be determined on the basis of estimation of the area of elementary population of the most important keystone species. On the territory of Northern Eurasia, these keystone species were large gregarious herbivores. The boundaries of potential ecosystems can be discerned by the change in composition of the keystone species represented. The sizes of real modern ecosystems and their boundaries depend on the land-use activity.

A distinction between the potential and the real ecosystem cover can be drawn starting from the times when humans began actively changing the biota of the Earth. In Northern Eurasia, this is the end of the paleolith - when the man started to actively hunt giant phytophages of the mammoth complex [46-50].

Under the modern conditions, when the majority of keystone animal and plant species is extinct or preserved in a small number of refugia, only model reconstruction is possible on most of the territories. It is a necessary tool for revealing the causes, underlying the reduction of species diversity in reserves, and for suggesting a complex of measures to solve the problem. The study of key species in the ecosystem refuges revealed a group of dependent species, whose life is caused by, or otherwise converted among key species. We see them as "indicator species". It was established that the indicator species, sustained by the environment-transforming activity of keystone species (first of all, large animal herbivores), were preserved in anthropogenically transformed ecosystems, provided the land-use activity on those territories partially imitated the influence of the keystone species. For example, pasturing livestock in forest and steppe sustained a great variety of light-demanding herbs and insect pollinators, which completely disappeared after introduction of the preservation regime and formation of dense forests and bushes [51-55].

Complex studies within the framework of historical ecology and ecology of ecosystems (synecology), which accumulated views of new paradigms, can become a necessary basis for novel approaches to the study and model reconstruction of the potential ecosystem cover.
Grounding of the notions of "potential ecosystem cover" and "potential ecosystem" becomes possible as a result of recognition of a new scientific discipline: historical ecology - and use of its concepts for development of synecology [39, 40, 44]. By now, researchers have amassed a great body of information within the frameworks of the continual, systemic and population-demographic paradigms, which replaced the paradigm of organism. This information made it possible to formulate new concepts, which changed the fundamental views on the structural-functional organization and dynamics of plant communities and ecosystems:

- "hierarchical continuum concept", which implies continuity of the vegetation cover at different levels of organization [56-62];

- "gap mosaic concept", which considers gaps in the forest canopy. These gaps appear as a result of death of old trees and the subsequent filling of the gaps with trees of a new generation, which also grow, die and fall [63-70];

- "mosaic cycle concept of ecosystem", which studies emergence, development and disappearance of mosaics in the ecosystems formed by representatives of different trophic groups of species: plants, animals, fungi etc. - in the course of their life and death [71-74];

- "natural disturbance concept", which investigates natural disturbances due to the life activities of all the ecosystem species of all the trophic groups [61, 75-77];

- concept of powerful transformer of ecosystems ("aedificator, keystone species, ecosystem engineer concept"), studying species that are powerful transformers of communities and ecosystems $[34,78-80]$;

- "population-demographic concept", according to which an ecosystem can be considered as a multitude of interrelated flows of generations in the elementary populations of all the species, which are integrated and controlled by the population life of powerful transformers of ecosystems ("aedificator or keystone species, or ecosystem engineer species") in the process of their interaction with the environment, its exploitation and transformation [81-89].

These concepts provided a basis for the shift from the organismic to ecosystem way of thinking. They allowed researchers to describe a great variety of structures and processes at different levels of organization of the ecosystem cover, which is necessary for model reconstructions of the potential ecosystem cover. The "hierarchical continuum concept" was first applied to the plant cover as a convenient model object. Further studies, which analyzed distribution of species of different trophic groups in the space of ecological factors, made 
grounds for the concept of continuous living cover of land surface at various hierarchical levels: from microsites and communities to the vegetation cover of climatic zones etc. Distinct boundaries between the elements of this cover only result from the physical obstacles of natural (rivers, rocky grounds without vegetation etc.) or anthropogenic (cuttings, arable lands, plantations etc.) character. Development of the concept of continuality led to the view that the cover is multi-layered: it includes not only above-ground, but under-ground layers as well. Each layer has its own mosaics (clusters of individuals of one or different species), which can be distinguished by one or another criterion and differ in their sizes and structural-functional types [62, 90-92].

Application of the concept of hierarchically subordinated continuum showed that, depending on the research objectives and resources, the plant and, then, all biotic cover can be divided into elements differently [92]. This made it difficult to choose the elements of the cover (plant communities and ecosystems), investigation of which would allow one to characterize the direction and rates of their dynamics after disturbances - and, correspondingly, their natural image. An approach to solution of this problem was suggested within the frameworks of the population-demographic concept [89].

The "gap mosaic concept", "mosaic cycle concept of ecosystem" and "natural disturbance concept" consider the permanent appearance, development and succession of structures of different kinds and lifespan within ecosystems, describing them at different angles. These structures are formed by the populations of species of different trophic groups, systematic positions and roles in the ecosystem. Each of these concepts describes and explains the mechanisms of formation of hierarchical space-time continuum already at the level of ecosystem cover [62].

The most known and popular among these concepts is the "gap mosaic concept", which made it possible to describe forest communities as a mosaic of constantly emerging gaps in the crown layer of the forest as a result of death of a few trees because of old age. Within these gaps, groups of young trees of one or several species grow; they mature, produce offsprings and - in their turn - die at the end of their ontogenesis [38, 63, 65, 68, 73]. The substantial differences in the sizes of adult plants and undergrowth determine physiognomically distinct elements of the "gap" mosaic (or spatial-temporal mosaics of patches, according to Putz et al. [93]), which were called "ontogenetic parcels" in Russian literature [37]. The use of the ontogenetic stage (instead of absolute age) of groups of trees allowed one to standardize the stages of elements of the "gap" mosaic - irrelatively of the duration of those stages [85].

In the forests with distinct "gap mosaic", one can clearly see the environment-transforming effects of trees $[65,74,77]$. They manifest themselves:

- in adult trees creating a sub-crown space with specific ecological characteristics of the environment (illumination, moisture, chemical composition of soils etc.) and specific inhabitants from different trophic groups [94, 95];

- in formation of uprooting and snapping complexes of trees, which appear as a result of death of trees because of old age [93].

Transformations of the environment in the process of life and death of single trees and their groups, as well as corresponding transformations of the soil cover result in the heterogenous mosaicity of forest ecosystems [96].

A wide spread of the concept of "gap mosaic" allowed researchers to standardize the analysis of succession processes in the forest ecosystems, describing them in the terms of this concept. At the early stages of restoration of forest vegetation after its complete destruction, there are still no elements of the "gap" mosaic. At the middle stages, elements of the "gap mosaic" begin to form, and the diversity of their types increases. At the final stages of succession, there are all the elements of the gap mosaic [97].

In the process of development of the "gap mosaic" concept, researchers turned their attention to formation of the mosaics generated during the life and death of plants, animals and fungi and other creatures. The results of studies of structure and dynamics of the mosaic elements, formed by the species of different trophic groups and roles in the ecosystem, provided a basis for the "mosaic cycle concept of ecosystem" [71].

The last concept from this group - the "natural disturbance concept" - is essentially the same as the "mosaic cycle concept of ecosystem". It describes various types of endogenous disturbances i.e., disturbances which result from life and death of all inhabitants of the ecosystem: vertebrate and invertebrate animals, plants, fungi etc.

Summarizing these concepts, we come to a quite evident conclusion that every species, inhabiting an ecosystem, changes the environment in the process of life and death of its individuals, and the species can be ranked by the potency of one or another effect on the environment, with the analysis of different effects yielding different ascending series.

Differences in the manner and intensity of environment transformation by different species were obvious even without quantitative characteristics 
of their effects. That is why already at the beginning of study of natural communities, some species, whose environment-transforming potency was the highest, were singled out and united into special groups. They were called "aedificators" (according to Braun-Blauquet, Pavillard [34]), i.e., builders of communities. This notion was widely used in Russian literature [78, 98-100].

Later, environment transformers, which were identified in various animal groups, were called "keystone species" [101-103] or "ecosystem engineers" [104-106]. Currently, there is a large body of literature devoted to these types of environment transformers. As follows from this literature, such species have a common feature, which is independent of the size of individuals, their trophic groups, specifics of their biology and ecology etc.: all those species possess a potent ability to transform environment in different ways, creating conditions for sustainable inhabitation of large, biologically and ecologically diverse groups of accompanying (dependent) species. As a result of these effects, the role of competitive relationships in the ecosystem decreases, whereas the role of complementary and mutualistic relationships rises [36, 107-110].

On the basis of this common trait - a powerful transformation of habitat - we consider these three terms as synonyms, and use the term "keystone species", as researchers use it in relation to the species of different trophic groups.

As the studies expand and more information is collected, the ranked series of environment transformers are gradually filled with the species of intermediate ranks. Ranking of species by the extent of their environment-transforming potency allows one to reach a deeper comprehension of the structural-functional organization of natural ecosystems and, at the same time, it is another manifestation of continuality of the living cover of the Earth: the existence of practically continuous series of species ranked by the intensity of environmenttransforming effects.

Understanding the necessity to investigate biology and ecology of every species in the analyzed ecosystems, we believe that the study of the keystone species, preserved up to now, and modeling of their historic areals becomes especially important regarding formation of views on the potential ecosystem cover.

A synthesis of the concept of populationdemographic organization of communities (or ecosystems) and the concept of keystone species allows one to solve a complex problem of synecology: determination of minimal areas in order to reveal potential ecosystems. To solve this problem, a notion of elementary population (elementary de- mographic unit) was formulated. Elementary population is the multitude of individuals of a single species that is necessary and sufficient to support stable alternation of generations in the least possible territory [89]. This notion is analogous to the notion of "minimal viability of a population", which was introduced earlier on the basis of zoological data [111].

Since we consider an ecosystem as a totality of generation flows in the elementary populations of species, interacting with the environment and united (controlled) by the population life of potent environment transformers, determination of the minimal area of the ecosystem will be based on determination of the total area occupied by the elementary populations of the keystone species. In the process of restoration of a disturbed ecosystem, elementary populations of keystone species will pass developmental stages from the invasive to the normal state [112]. It is this state that is characterized by a stable flow of generations. It was shown that on areas sufficient for stable flows of elementary populations of keystone species, dependent species were also able to form sustainable elementary populations. It should also be noted that the area inhabited by an elementary population of one keystone species can contain several elementary populations of a certain dependent species [37, 88-89].

The concepts described above allow one to approach the classical ideas of F. Clements [5] and E. Odum [36] about successions and climax on a new basis, with autogenic successions being regarded as a path to restoration of the potential ecosystem cover and climax as the achievement of its steady state.

The notions of "succession" and "climax" are basic - both in development of theoretical problems of synecology and in making responsible decisions in the process of nature management and conservation biology. These notions have a long history of their formation and development, and yet the modern ecology lacks a clearly defined system of concepts, necessary for the study of these complex processes [80].

The main propositions of such a system can be formulated on the basis of a synthesis of the concepts reviewed above.

1. Ecosystem is a multitude of populations of species of different trophic groups (which together make the biota of the ecosystem) in the process of interaction with each other and transformation of abiotic components of the environment in a certain ecotope.

2. Succession is a process of formation (primary succession) or restoration (secondary succession) of flows of generations in the populations of all the species of the biota of the ecosystem, which 
is aimed at full realization of their potential in a certain ecotope.

3. Climax is a process of maintenance of stable flows of generations in the populations of all the biota species, whose ecological needs are fully realized when the ecosystem reaches a dynamically steady state in a certain ecotope.

4. Autogenic time of succession is an interval from the beginning of the ecosystem development to the moment of its transition to the climax state. Autogenic time of succession can only be determined under the condition of its undisturbed existence, i.e., if the ecosystem develops spontaneously. Such a type of ecosystem development was defined as "autogenic succession" [35].

5. Autogenic space of an ecosystem is formed in the course of autogenic succession and is fully realized in the climax state. Autogenic space of an ecosystem is a result of formation and interaction of the population mosaics of keystone and dependent species in the course of autogenic succession from the initial to the climax state.

6. A relative autonomy of the biota of a climax ecosystem from the environment and its environment-transforming function is achieved as a result of activation of the structural-dynamic and matterenergy processes in the course of autogenic successions.

7. The driving force of autogenic succession is the environment-transforming activity of the populations of keystone species, which leads to formation of a biotically determined heterogeneous environment of the ecosystem. As a result, the ecological capacity of the ecosystem constantly enhances, and the ecological and taxonomic diversity increases. The growth of heterogeneity of the ecosystem environment from the initial stages of succession to the final stages and climax reduces the significance of competitive relationships in the organization of the ecosystem, while making complementary and mutualistic relationships more important.

Thus, the following conclusions can be made in view of the main concepts of synecology.

1. The sizes (linear sizes, area and volume), composition and structure of climax ecosystems can be determined on the basis of field studies and/or reconstructions of the population mosaics of the most powerful keystone species and their relationships with the dependent species.

2. The simultaneous presence of keystone species with different sizes of their population mosaics in a climax ecosystem determines their mosaichierarchical structure.

3. The boundaries of climax ecosystems are determined or reconstructed by the change of sets of the most powerful keystone species.
4. The sizes, composition and structure of successive ecosystems at every stage of their development are a result of interaction of exogenous and endogenous factors: dominating at the initial stages the former, and at the final stages - the latter.

5. It is expedient to specify if an ecosystem is climax or successive, since at the beginning of its formation, all the main parameters (sizes, composition, structure, rates of development) are primarily determined by the environment (successive ecosystem), and at the end, by the biota (climax ecosystem).

The theses formulated above were tested on the materials of the field research [38]. This allowed us to suggest a new model of autogenic succession, which we called a saturation model. The essence of the model is the following: each new species (or a new group of species), introducing into an ecosystem, transforms the ecosystem environment in the process of its population life, making it more heterogenic. Thereby, coexistence of both preceding and successive species companies is maintained. In the process of ecosystem development according to the saturation model, the environment-transforming functions of the biota are enhanced, its production grows and the ecological capacity of the ecotope increases. These processes are accompanied by the growth of the structural and taxonomic diversity of the ecosystem [80].

A saturation model type of ecosystem development can only occur, when there are no obstacles for introduction of seeds and survival of all the potential inhabitants of the ecosystem. Difficult or even impossible as it is to be found in nature, such a model of autogenic succession is a very handy research tool. It enables one to reveal ecosystem potencies in a certain climatic situation, and it can be considered a standard for evaluation of the extent of deviation of natural ecosystems from the optimal path of their development. This procedure is a necessary step to the model reconstructions of the potential ecosystem cover.

Attempts to reconstruct the potential ecosystem cover on the basis of the analysis of areals of keystone and dependent species are rare [38, 42, 113]. At the same time, grounds for such constructions have already been created. On the one hand, they include studies of population biology of keystone and dependent plant species [37, 38, 72, 82-86, 114]; on the other hand, studies of keystone animal species [72, 94, 115-122]. Together, these studies have covered a great variety of species of different life forms, ecological groups, types of strategy and specifics of environment transformation.

The use of the population-demographic concept of organization of ecosystems enables one to review the problem of successions and climax at a new level of knowledge [80]. 
To resolve this problem within the framework of the population-demographic concept one needs the following:

1. Analyzing objects in hierarchical series, one should abide by the principle of emergence: an ecosystem should not be viewed as a multitude of interacting individuals [99], but considered as a multitude of interrelated elementary populations with all their intrinsic properties.

2. It is necessary to distinguish between dynamic processes at different levels of organization of an ecosystem cover: intra-ecosystem, ecosystem and complexes of ecosystems. The term "succession" should only be applied to ecosystems themselves in the dynamic disturbance-torestoration series.

3. Model succession series of ecosystems should be based on the stages of development (invasive, normal, regressive) of the populations of keystone species [123].

4. The minimal area that potential ecosystems are to be revealed upon should be determined on the basis of the total area requiring maintenance of stable flows of generations of plant and animal keystone species.

5. It is necessary to consider autogenic succession as a process of formation of intra-ecosystem mosaics of various types, sizes and lifetimes - a process which is directed and regulated by the flows of generations of the elementary populations of keystone species.

6. For prognoses of the structural-functional organization and a level of biological diversity of potential ecosystems of different types, it would be appropriate to use a saturation model [80].
The synecological concepts discussed above provided a basis for the model reconstructions of the modern potential forest cover of European Russia [38, 113].

The first step along this road was made during the study of elementary populations of various tree species in the forests of Eastern Europe. Using the method of increasing areas in the forest communities with stable flow of generations, the minimal and total elementary-population areas were determined for various tree species [37, 72, 88, 89, 124-126]. Then, historic areals of the preserved keystone species from different functional groups (various tree species, aurochs and other large gregarious herbivores, beavers and some dependent species from different Holocene periods) were reconstructed [38, 43, 127].

On the basis of literature and our own data, we developed a system of measures aimed at creation and support of the elementary populations of keystone species of different functional groups. We also determined sizes of their areas, as well as types and sizes of the intra-population mosaics (specific ecotopes), formed in the process of environmenttransforming activity by keystone species of different functional groups.

Comparison of the data obtained shows that the difference in the size of the areas, on which a flow of generations of elementary populations of keystone species of different functional groups is realized, amounts to four orders of magnitude. In these flows of generations, various intra-population mosaics are formed; they differ in their types and sizes and are most diverse in the animal keystone species, especially beavers (Table 1, Fig. 1-3).

Table 1

The hierarchical system of sites of key species of different functional groups

\begin{tabular}{|c|c|c|c|c|}
\hline $\begin{array}{l}\text { Microsites: } \\
\mathrm{m}^{2}-\text { tens } \mathrm{m}^{2}\end{array}$ & \multicolumn{2}{|c|}{$\begin{array}{c}\text { Mezosites: } \\
\text { dozens } \mathrm{m}^{2}-\text { hundreds } \mathrm{m}^{2}\end{array}$} & $\begin{array}{l}\text { Macrosites: } \\
\text { tens of thousands } \mathrm{m}^{2}- \\
\text { hundreds of thousands } \mathrm{m}^{2}\end{array}$ & $\begin{array}{c}\text { Megasites: } \\
\text { tens } \mathrm{km}^{2}-\text { hundreds } \mathrm{km}^{2}\end{array}$ \\
\hline \multicolumn{4}{|c|}{ Functional group - trees of different species } & \\
\hline $\begin{array}{l}\text { Pits, mounds (Fig. 1,A), } \\
\text { fallen logs (Fig. } 1, B \text { ), } \\
\text { stumps, area under the } \\
\text { tree's crown, the area } \\
\text { between the tree's crown }\end{array}$ & \multicolumn{2}{|c|}{$\begin{array}{l}\text { Ontogenetic «parcels»- } \\
\text { different elements } \\
\text { of gap-mosaic (Fig. } 1, C \text { ) }\end{array}$} & $\begin{array}{l}\text { Collection of all types } \\
\text { of sites in the area } \\
\text { of elementary tree } \\
\text { population }\end{array}$ & \\
\hline \multicolumn{5}{|c|}{ Functional group - beaver } \\
\hline \multicolumn{2}{|c|}{$\begin{array}{l}\text { Burrows, settlement (Fig. } 2, A \text { ), trails, } \\
\text { stumps with cuts beavers, dams } \\
\text { (Fig. } 2, B \text { ), channels }\end{array}$} & \multicolumn{2}{|c|}{$\begin{array}{l}\text { Glades (Fig. 2,C), ponds ((Fig. 2,D), } \\
\text { swamp forests (Fig. 2,E) and meadows, } \\
\text { mires }\end{array}$} & $\begin{array}{l}\text { Collection of all types of sites } \\
\text { in the area of elementary } \\
\text { beaver population }\end{array}$ \\
\hline \multicolumn{5}{|c|}{ Functional group - large gregarious herbivorous - bison } \\
\hline $\begin{array}{l}\text { Resting, dug and ride } \\
\text { places }\end{array}$ & \multicolumn{2}{|c|}{$\begin{array}{l}\text { Collective trails, parking } \\
\text { small groups Fig. } 3, A\end{array}$} & $\begin{array}{l}\text { Watering and meadow } \\
\text { glades, light forests Fig. } 3, B\end{array}$ & $\begin{array}{l}\text { Collection of all types of sites } \\
\text { in the area of elementary bison } \\
\text { population Fig. 3,C }\end{array}$ \\
\hline
\end{tabular}




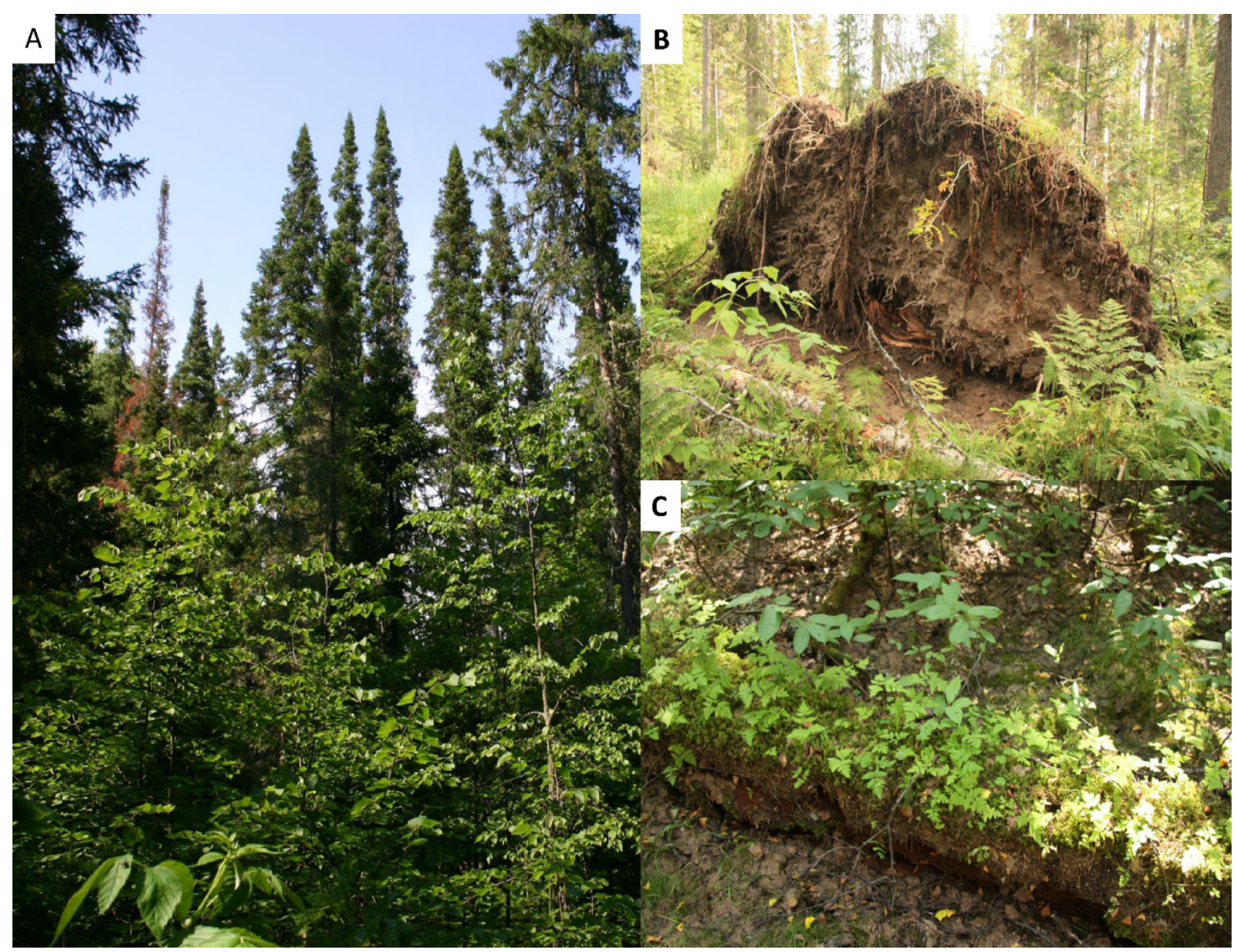

Fig. 1. Intra-population mosaics:

$A$ - pit and mound in the boreal forest of the Pechora-Ilych Biosphere Reserve, Komi Republic, Russia (Photo A. Aleynikov); B - small fern (Gymnocarpium dryopteris) on fallen logs (deadwood) in the boreal forest of the Pechora-Ilych Biosphere Reserve, Komi Republic Russia

(Photo A. Aleynikov); C - young lindens in the gap created after death of old fir-trees in the hemiboreal forest of the Sabarsky wildlife area, Central Ural Mountains (Photo M. Barinova)

Constructing a system of habitats, which is created and supported by the elementary populations of keystone species of different functional groups, is of principal importance regarding formation of approaches allowing one to reconstruct the potential ecosystem cover. Such a system:

1) makes it possible to estimate the areas for identification of the pre-historic forest ecosystems with representatives of all the functional groups of keystone species;

2) makes it clear that the minimal area of their identification covers all the series of habitats, from automorphic to hydromorphic, within the basin of a small river;

3) demonstrates that the largest diversity of habitats of forest ecosystems was formed in the process of population life of large gregarious herbivores and beavers;

4) indicates that the represented pre-historic forest landscapes united detrital-pasture formations, whereas the modern distinction of isolated detrital and pasture ecosystems in the forest cover is a result of anthropogenic transformation of the united forest cover;

5) suggests that the so-called ecosystems of watershed forests, valley forests, aurochs clearings, beaver meadows, swamps and ponds, which are clearly distinguishable now, are fragments (shards) of a potential forest ecosystem - the potential forest landscape;

6) leads one to a conclusion that at the current level of anthropogenic transformation of ecosystem cover, the notions of "potential ecosystem cover" and "climax state of ecosystem" should only be used as model ones.

The model reconstructions performed remove discrepancies between the paleobotanics data on cohabitation of light-demanding and shade-tolerant tree species within prehistoric forests and the contemporary species composition of shadow forests $[20,37$, $38]$. In addition, the causes of the drop in species diversity of photophilous flora, which is registered in forest reserves, are revealed [126, 128, 129]. 

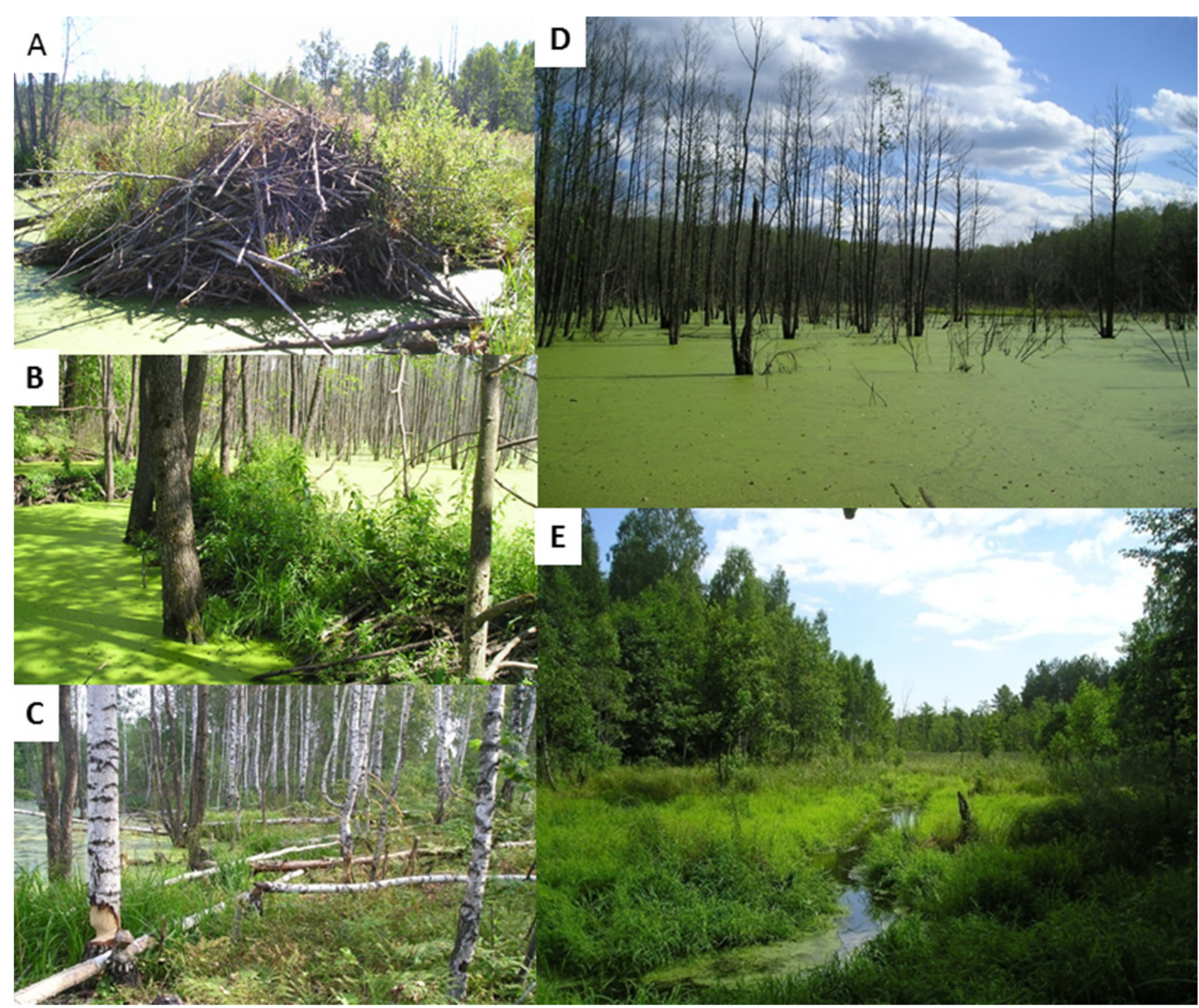

Fig. 2. Intra-population mosaics:

$A$ - beaver settlement in the valley Skutyanka, the "Bryansk Forest" reserve, the European part of Russia (Photo A. Aleynikov); B - beaver damb in the valley Skutyanka, the "Bryansk Forest" reserve, the European part of Russia (Photo A. Aleynikov); C - cutting area made by beaver ("beaver glades") in the valley Skutyanka, the "Bryansk Forest" reserve, the European part of Russia (Photo A. Aleynikov); D - beaver pond in the valley

Skutyanka, the "Bryansk Forest" reserve, the European part of Russia (Photo A. Aleynikov); E - peat bog on the site overgrown beaver pond in the valley Skutyanka, the "Bryansk Forest" reserve, the European part of Russia (Photo A. Aleynikov)

The model reconstruction demonstrates utmost importance of those forest reserve territories, where historic areals of keystone animal species are being restored - spontaneously or with the help of the man. Such territories are natural laboratories, where restoration of the populations of keystone animal species can be accompanied by restoration of lightdemanding species of trees, shrubs and herbs, as well as representatives of other trophic groups - as a result of spontaneous dissemination of diaspores or human-assisted reintroduction.

There is no doubt that, as natural biodiversity on those territories is restored, their hydrological regime, local climate, productivity and other ecosystem functions will change, allowing one to gather more detailed data on the ecosystem cover of those local territories. Combining data from different regions will make it possible to theoretically reconstruct the ecosystem cover of larger territorial divisions.

Speaking about possibilities of theoretical reconstruction of the potential ecosystem cover, one should note that there are essential differences between such reconstructions in respect to forests and steppes of European Russia. A historical analysis shows that steppe and forest-steppe territories were formed in the late Holocene as a result of anthropogenic aridization of plant cover and replacement of wild keystone steppe and forest-steppe species (wild horses, aurochs, tarpans, koulans, saigas, dzerens) with domestic animals $[37,38]$. 
Long-term observations of dynamics of ecosystems in steppe and forest-steppe reserves of European Russia showed that gradual replacement of wild ungulates with domestic animals preserved a part of dependent species of plants, animals and representatives of other kingdoms. For example, breeding horses at the stud farms, practicing moderate pasturing, preserved colorful meadow steppes of the Central-Chernozem Reserve up to the beginning of their reservation. At the same time, introduction of the regime of total reservation on this and similar territories resulted (and continues to result) in a catastrophic drop in species diversity. The colorful meadow and true steppes began and continue to turn into species-poor tree-shrub communities [52-55, 130-132].

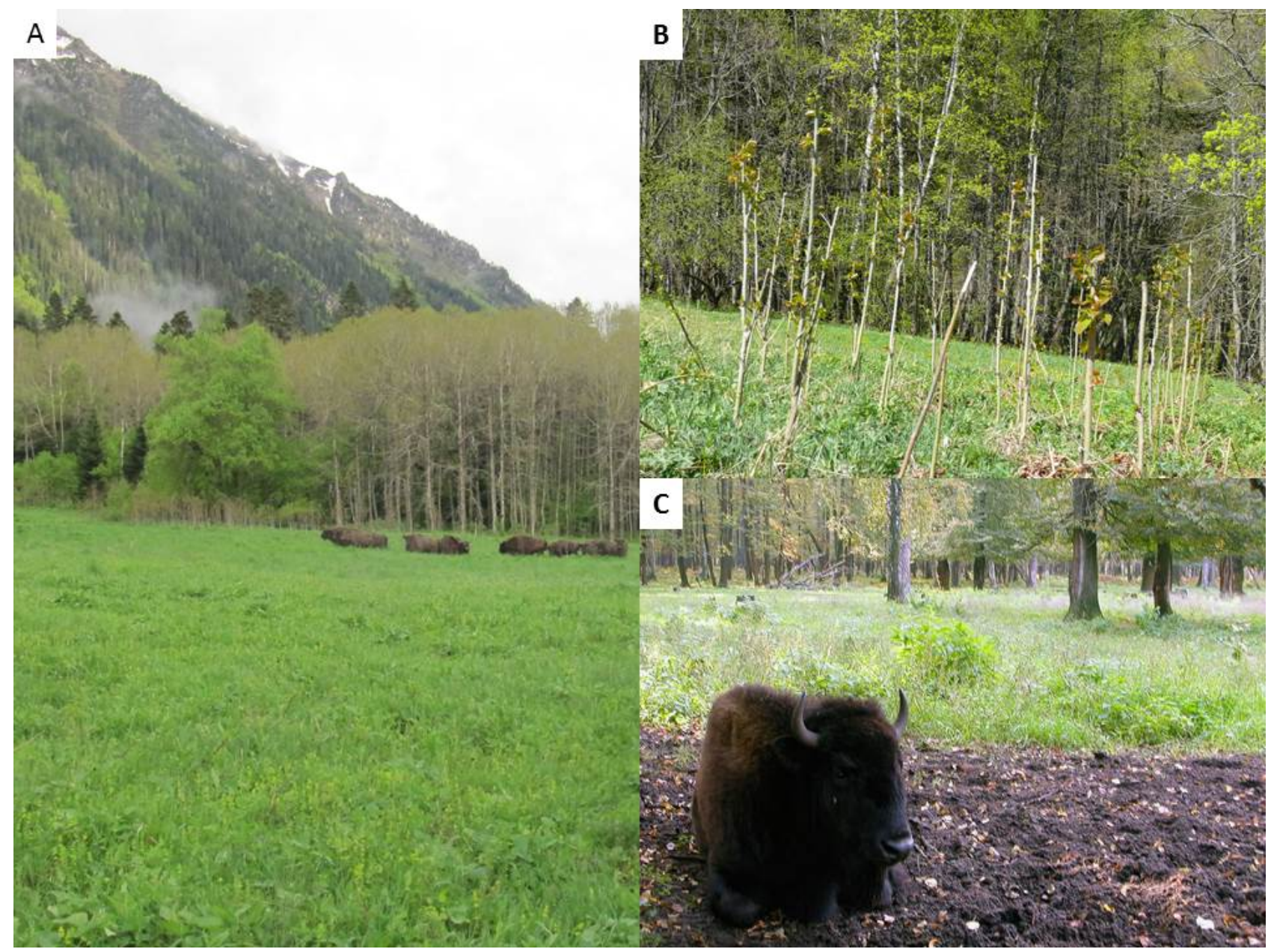

Fig. 3. Intra-population mosaics:

A - naked soil on a bison herd stand in the gemiboreal forest of the "Bialowieza Forest" reserve, Belarus (Photo V. Korotkov); B - young aspen, damaged by bisons on forest glades in the "Kaluga zaseki" reserve, the European part of Russia (Photo M. Bobrowski); C - complex of forest and meadow landscapes of the elementary population of bisons in "the Teberdinsky reserve", the Northwest Caucasus (Photo N. Shevchenko)

In spite of incompleteness of model reconstructions of the potential ecosystem cover, they are necessary to prevent or lower the risks of reservation $[133,134]$. A vast body of experience on spontaneous and/or regulated restoration of biological diversity in reserves of various types should become the basis for such reconstructions. Analysis and summation of this experience will make it possible to develop series of programs oriented towards the maximal possible restoration of natural diversity. The ideas discussed above can be realized under the condition of complex research in reserves, representing a part of the preserved keystone and dependent species or practicing their active invasion.

\section{Conclusion}

The analysis of modern literature on synecology and historical ecology enabled us to breathe new life into the classical idea of R. Tuxen about "potential vegetation". Appearance and development of fundamentally new synecological concepts, resulting from the change of paradigms in biology, make it possible to advance a new meth- 
odology and methods of analysis of not a mere plant one, but the entire ecosystem cover. At the same time, formation of a system of synecological concepts stimulated a review of F. Clements's classical ideas about successions and climax in respect to the ecosystem as a whole. On the basis of this approach, a new understanding of climax as a state of ecosystems, in which their potencies are fully realized, was formulated. We consider model reconstructions of the potential ecosystem cover as a necessary basis for assessment of the modern state of reserves and their prospects of conservation and/or restoration of natural biodiversity.

\section{Acknowledgements}

We thank Larisa Khanina, Maxim Bobrovsky, Vladimir Korotkov, Alexey Aleynikov and Nikolay Shevchenko for remarks, a valuable advice and illustrative materials.

\section{References}

1. Gamfeldt L., Hillebrand H., Jonsson P. R. Multiple functions increase the importance of biodiversity for overall ecosystem functioning. Ecology. 2008, vol. 89 (5), pp. 1223-1231.

2. Ecosystem and biodiversity economics: potential and prospects of Northern Eurasian countries: proceedings of the conference «Project TEEB - ecosystem and biodiversity economics: participation prospects of Russia and other members of NIS». Moscow, 2010, $136 \mathrm{p}$.

3. Pavlov D. S., Bukvareva E. N. Climate-regulating functions of ground ecosystems and the ecology-focused conception of nature management. Progress of modern biology. 2011, vol. 131, no. 4, pp. 324-345.

4. Tuxen R. Modern potential of natural vegetation as an object for plant cover mapping. Applied plant sociology (Stolzenau). 1956, vol. 13, pp. 4-42.

5. Clements F. E. Nature and structure of the climax. Journal of Ecology. 1936, vol. 24, pp. 254-282.

6. Westhoff V., Van der Maarel E. The Braun-Blanquet approach. Handbook of Vegetation Science. V. Ordination and classification of communities. Ed. by R. H. Whittaker. The Hague, 1973, pp. 617-726.

7. Brzeziecki B., Kienast F., Wildi O. A simulation map of the potential natural forest vegetation of Switzerland. J. Veget. Sci. 1993, vol. 4, no. 2, pp. 149-156.

8. Stumpel A. H. P., Kalkhove J. T. R. A vegetation map of the Netherland, based on the relationship between ecotypes and types of potentional natural vegetation. Vegetatio. 1978, vol. 37, pp. 1167-1179.

9. Chytry M. Potential replacement vegetation: An approach to vegetation mapping of cultural landscapes. Applied Vegetation Science. 1998, vol. 1, pp. 177-188.

10. Ricotta C., Carranza M. L., Avena G., Blasi C. Are potential natural vegetation maps a meaningful alternative to neutral landscape models? Applied Vegetation Science. 2002, vol. 5, pp. 271-275.

11. Kelly A., Powell D. C., Riggs R. A. Predicting Potential Natural Vegetation in an Interior Northwest Landscape Using Classification Tree Modeling and a GIS. Western Journal of Applied Forestry. 2005, vol. 20, no. 2, pp. 117-127.

12. Hall M. J. G., McGlone Matt S. Potential forest cover of New Zealand as determined by ecosystem process model. New Zealand Journal of Botany. 2006, vol. 44, pp. 211-232.

13. Leuschner $\mathrm{C}$. The concept of a potential natural vegetation (PNV): problems and suggested improvements. Flora. 1997, vol. 1, pp. 431-436.

14. Brunet J., Fritz O., Richnau G. Biodiversity in European beech forests - a review with recommendations for sustainable forest management. Ecological Bulletins. 2010, vol. 53, pp. 77-94.

15. Bobiec A., Kuijper D. P. J., Niklasson M., Romankiewicz A., Solecka K. Oak (Quercus robur L.) regeneration in early successional woodlands grazed by wild ungulates in the absence of livestock. Forest ecology and management. 2011, vol. 262, pp. 780-790.

16. Hickler T., Vohland K., Feehan J., Miller P. A., Smith B., Costa L., Giesecke T., Fronzek S., Carter T. R., Cramer W., Kühn I., Sykes M. T. Projecting the future distribution of European potential natural vegetation zones with a generalized, tree species-based dynamic vegetation model. Global Ecology and Biogeography. 2012, vol. 21, pp. 50-63.

17. Connell J. H., Slatyer R. O. Mechanisms of succession in natural communities and their role in community stability and organization. The American Naturalist. 1977, vol. 111, no. 982, pp. 1119-1144.

18. Stone L., Ezrati S. Chaos, cycles and spatiotemporal dynamics in plant ecology. Journal of Ecology. 1996, vol. 84, pp. 279-291.

19. Pickett S. T. A., Cadenasso M. L., Meiners S. J. Ever since Clements: from succession to vegetation dynamics and understanding to intervention. Applied Vegetation Science. 2008, vol. 12, pp. 9-21.

20. Vera F. W. M. Grazing ecology and forest history. Oxon, New York: CABI Publishing, 2000, 506 p.

21. Carranza M. L., Ricotta C., Fortini P., Blasi C. Quantifying landscape change with actual vs. potential natural vegetation maps. Phytocoenologia. 2003, vol. 33, pp. 591-601.

22. Carrio'n J. S., Fernandez S. The survival of the "natural potential vegetation" concept (or the power of tradition). J. of Biogeography. 2009, vol. 36, pp. 2202-2203.

23. Carrio'n J. S. The concepts of potential natural vegetation (PNV) and other abstraction (trying to pick up fish with wet hands). J. of Biogeography. 2010, vol. 37, pp. 2213-2215. 
24. Chiarucci A., Araujo M. B., Decocq G., Beierkuhnlein C., Fernandez-Palacios J. M. The concept of potential natural vegetation: an epitaph? J. of Vegetation Science. 2010, vol. 21, pp. 1172-1178.

25. Loidi J., Fernandez-Gonzalez F. Potential natural vegetation: reburing or reboring. J. of Vegetation Science. 2012, vol. 23, pp. 596-604.

26. Zerbe S. Potential natural vegetation: validity and applicability in landscape planning and nature conservation. $A p-$ plied Vegetation Science. 1998, vol. 1, pp. 165-172.

27. Aguilar M. J. A., Gonzalez-Gonzalez R., Garzon-Machado V., Pizarro-Hernandez B. Actual and potential natural vegetation on the Canary Islands and its conservation status. Biodiversity and Conservation. 2010, vol. 11, pp. 3089-3140.

28. Farris E., Filibeck G., Marignani M., Rosati L. The power of potential natural vegetation (and of spatial-temporal scale): a response to Carrio'n \& Fernandez. J. of Biogeography. 2010, vol. 37, pp. 2211-2213.

29. Zampieri M., Lionello P. Simple statistical approach for computing land cover types and potential natural vegetation. Climate Research. 2010, vol. 41, pp. 205-220.

30. Vaca R. A., Golicher D. J., Cayuela L. Using climatically based random forests to downscale coarse-grained potential natural vegetation maps in tropical Mexico. Applied Vegetation Science. 2011, vol. 14, pp. 388-401.

31. Wang H., Ni J., Prentice I. C. Sensitivity of potential natural vegetation in China to projected changes in temperature, precipitation and atmospheric $\mathrm{CO}_{2}$. Regional Environmental Change. 2011, vol. 11, pp. 715-727.

32. Somodi I., Molnar Z., Ewald J. Toward a more transparent use of the potential natural vegetation concept - an answer to Chiarucci et al. J. of Vegetation Science. 2012, vol. 23, pp. 590-595.

33. McIntosh R. P. The Myth of Community as Organism. Perspectives in biology and medicine. 1997, vol. 41, no. 3, pp. 426-438.

34. Braun-Blauquet J., Pavillard J. Vocabulaire de sociologie vegetale. 2nd ed. Montpellier, 1925, 22 p.

35. Odum E. P. Ecology. New York: Holt, Rinehart and Winston, 1963, 152 p. (Modern Biology Series).

36. Odum E. P. Strategy of ecosystem development. Science. 1969, vol. 164, pp. 262-270.

37. Eastern European broad-leaved forests. Edited by O.V. Smirnova. Moscow: Science, 1994, 364 p.

38. Eastern European forests: history in the Holocene and modern times. Edited by O. V. Smirnova. Moscow: Science, 2004, bk. 1, 479 p.; bk. 2, 575 p.

39. Bobrovskii M.V. Forest soils of European Russia: biotic and anthropogenic formation factors. Moscow: KMK, $2010,359 \mathrm{p}$.

40. Kyuster Kh. History of forests. A view from Germany: translation from German. Moscow: Higher school of economics, 2012, $304 \mathrm{p}$.

41. Vera F. W. M., Bakker E., Olff H. Large herbivores: missing partners of western European light-demanding tree and shrub species? Large herbivore ecology, ecosystem dynamics and conservation. Biology series. Ed. by K. Danell, P. Duncan, R. Bergstrom, J. Pastor. Cambridge University Press, 2006, pp. 203-231.

42. Smirnova O. V., Turubanova S. A., Bobrovskii M. V., Korotkov V. N. and others Historical reconstruction of the biocenotic cover of Eastern Europe and the problem of biological diversity preservation. Progress of modern biology. 2001, no. 2, pp. 144-159.

43. Smirnova O.V., Kalyakin V. N., Turubanova S. A., Bakun E. Y. Genesis of the Eastern European taiga in the Holocene. Regularities of secular dynamics of biogeocenoses. XXI reading in the memory of academician $V$. N. Sukachev. Moscow: KMK, 2006, pp. 18-65.

44. The ecological history of European forest. Ed. by K. Kirby, C. Watkins. Cambridge: Cambridge University Press, 1998,384 p.

45. Vernadsky V. I. The Biosphere and the Noosphere. Amer. Scientist. 1945, vol. 33, pp. 1-12.

46. Kuzmina I. E. Formation of Northern Ural's theriofauna in the late Anthropogene. Proceedings of Zoological Institute of AS USSR. 1971, vol. 49, pp. 44-122.

47. Vereshchagin N. K., Gromov I. M. Formation of theriofauna of USSR in the Quaternary. Progress of modern theriology. Moscow: Science, 1977, pp. 32-45.

48. Puchkov P. V. Uncompensated Wurm extinctions. Message 2. Environmental transformation by giant phytophages. Bulletin of zoology. 1992, no. 1, pp. 58-66.

49. Zhegallo V. I., Kalandadze N. N., Kuznetsova T. V., Rautian A. S. Fate of the Holarctic megafauna in the late Anthropogene. The mammoth and its environment: 200 years of research. Moscow: Geos, 2001, pp. 287-306.

50. Kaluakin V. N. On causes and consequences of the collapse of mammoth faunas. Progress of modern biology. 2014, vol. 134, no. 1, pp. 81-96.

51. Bobrovskaya N. I., Kazantseva T. I., Pashchenko A. I., Tishchenko V. V. Vegetation restoration of meadow steppes of the Central-Chernozem zone (Stony steppe). Arid ecosystems. 2000, no. 12, pp. 150-159.

52. Bobrovskaya N. I., Kazantseva T. I., Pashchenko A. I., Tishchenko V. V. Species composition change of a meadow-steppe fallow in the process of its transformation into a forest group. Steppes of Northern Eurasia: proceedings of VI International symposium. Orenburg, 2012, pp. 105-111.

53. Kazantseva T. I., Bobrovskaya N. I., Pashchenko A. I., Tishchenko V. V. Vegetation dynamics of a 100-years-old steppe fallow (Stony steppe, Voronezh region). Botanical journal. 2008, vol. 93, no. 4, pp. 620-633.

54. Kazantseva T. I., Bobraovskaya N. I., Tishchenko V. V. Features of restoration of fallow vegetation of meadow steppes of the Central Chernozem area (Voronezh region). Arid ecosystems. 2010, vol. 16, no. 2 (42), pp. $76-86$. 
55. Lysenko G. N. Steppe reserves and the absolute reserve mode: search for a compromise. Steppe bulletin. 2014, no. 40, pp. 11-15.

56. Allen T. F. H., Starr T. B. Hierarchy: perspectives for ecological complexity. Chicago: Univ. of Chicago Press, $1982,216 \mathrm{p}$

57. O'Neill R. V., De Anglis D. L., Waide J. B., Allen T. F. H. A hierarchical concept of the ecosystem. Princeton, New Jersey: Prinston Univ. Press, 1986, 196 p.

58. Pickett S. T. A., Collins S. L., Armesto J. J. A hierarchical consideration of causes and mechanisms of succession. Vegetatio. 1987, vol. 69, pp. 109-114.

59. Acker S. A. Vegetation as a component of non-nested hierarchy: a conceptual model. J. of Vegetation Science. 1990, vol. 1, no. 5, pp. 683-690.

60. Collins S. L., Glenn S. M., Roberts D. W. The hierarchical continuum concept. J. of Vegetation Science. 1993, vol. 4, no. 2, pp. 149-156.

61. Andel J. van. A population ecological approach to evaluate the rate of disturbance of plant communities. Proc. of VI Inter. Ecol. Cong. Manchester, 1994, pp. 30-35.

62. Smirnova O. V., Zaugolnova L. B., Popadyuk R. V. The hierarchical continuum concept as a basis for analysis of succession processes and development of biodiversity preservation methods. Succession processes in Russian nature reserves and problems of biodiversity preservation. Saint-Petersburg, 1999, pp. 14-26.

63. Watt A. S. Pattern and Process in plant communities. Journal of Ecology. 1947, vol. 35, pp. 1-22.

64. Aubreville A. Regeneration patterns in closed forest of Ivory Coast. Word vegetation types. NewYork: Columbia Univ. Press, 1971, pp. 41-55.

65. Falinski J. B. Uprooted trees, their distribution and influence on primeval forest biotope. Vegetatio. 1978, vol. 38, no. 3, pp. 175-183.

66. Brokaw N. V. L., Scheiner S. M. Species composition in gaps and structure of a tropical forest. Ecology. 1989, vol. 70, no. 3, pp. 538-541.

67. Korotkov V. N. A new paradigm in forest ecology. Biological sciences. 1991, no. 8, pp. 7-20.

68. Acevedo M. F., Urban D. L., Ablan M. Transition and gap models in forest dynamics. Ecological Applications. 1995 , vol. 5, pp. 1040-1055.

69. McCarthy J. Gap dynamics of forest trees: A review with particular attention to boreal forest. Environ. Rev. 2001, vol. 9, pp 1-59.

70. Mysterud A., Bartoń K. A., Jędrzejewska B., Krasiński Z. A., Niedziałkowska M., Kamler J. F., Stenseth N. C. Population ecology and conservation of endangered megafauna: the case of European bison in Białowieża Primeval Forest, Poland. Animal Conservation. 2007, vol. 10 (1), pp. 77-87.

71. The mosaic-cycle concept of ecosystem. Ed. by H. Remmert. Berlin; Heidelberg; NewYork: Springer-Verlag, 1991, $168 \mathrm{p}$.

72. Smirnova O. V. Population organization of the biocenotic cover of forest landscapes. Progress of modern biology. 1998, no. 2, pp. 25-39.

73. Bobiec A., Burgt H., Meijer K., Zuyderduyn C., Haga J., Vlaanderen B. Rich deciduous forests in Białowieża as a dynamic mosaic of developmental phases: premises for nature conservation and restoration management. Forest ecology and management. 2000, vol. 130, pp. 159-175.

74. McCarthy J. W., Weetman G. Age and size structure of gap-dynamic, old-growth boreal forest stands in Newfoundland. Silva Fennica. 2006, vol. 40 (2), pp. 209-230.

75. The ecology of natural disturbance and patch dynamics. Orlando: Acad. press, 1985, $472 \mathrm{p}$.

76. Disturbance Dynamics in Boreal Forest: Defining the Ecological Basis of Restoration and Management of Biodiversity. 2002, vol. 36 (1), 447 p.

77. Seidl R., Fernandes P. M., Fonseca T. F., Gillet F., Jönssong A. M., Merganicová K., Netherer S., Arpaci A., Bontemps J.-D., Bugmann H., González-Olabarria R. J., Laschn P., Meredieuo C., Moreira F., Schelhaas M.-J., Mohrenr F. Modelling natural disturbances in forest ecosystems: a review. Ecological Modelling. 2011, vol. 222, pp. 903-924.

78. Sukachev V. N. Plant communities (Introduction into phytosociology). Moscow; Leningrad: Book, 1928,58 p.

79. Hastings A., Byers J. E., Crooks J. A. Ecosystem engineering in space and time. Review and synthesis. Ecol. Lett. 2008, vol. 10, pp.153-164.

80. Smirnova O.V., Toropova N. A. Succession and climax as an ecosystem process. Progress of modern biology. 2008, no. 2, pp. 129-144.

81. Rabotnov T. A. Problems in studying a population composition for phytocenological purposes. Problems of botany. Moscow; Leningrad, 1950, issue 1, pp. 465-483.

82. Cenopopulations of plants (basic concepts and structure). Moscow: Science, 1976, $216 \mathrm{p}$.

83. Cenopopulations of plants (development and interaction). Moscow: Science, 1977, $134 \mathrm{p}$.

84. Cenopopulations of plants (population biology essays). Moscow: Science, 1988, $184 \mathrm{p}$.

85. Gatzuk L. E., Smirnova O. V., Vorontzova L. I., Zaugolnova L. B., Zhukova L. A. Age states of plants of various growth forms: a review. Journal of Ecology. 1980, vol. 68, no. 3, pp. 675-696.

86. The population structure of vegetation. Handbook of vegetation science. Ed. by J. White. Dodrecht; Boston; Lancaster, $1985,362 \mathrm{p}$.

87. Smirnova O. V., Zaugolnova L. B., Istomina I. I., Khanina L. G. Population mosaic cycles in forest ecosystems. Proceedings IAVS Symposium. Uppsala: Opulus Press, 2000, pp. 108-112. 
88. Smirnova O. V., Popuadyuk R. V., Chistyakova A. A. Population methods for determination of the minimal area of forest cenosis. Botanical journal. 1988, vol. 73, no. 10, pp. 1423-1434.

89. Smirnova O. V., Zaugolnova L. B., Popadyuk R. V. The population concept in biocenology. Journal of general biology. 1993, vol 54, no. 4, pp. 438-448.

90. Mordkovich V. G., Shatokhina N. G., Titlyanova A. A. Steppe catenas. Novosibirsk: Science, 1985,117 p.

91. Methodological approaches to ecological assessment of a forest cover in a small river basin. Edited by L. B. Zaugolnova, T. Y. Braslavskaya. Moscow: KMK, 2010, 383 p.

92. Mirkin B. M., Naumova L. G. Modern condition of main vegetation science concepts. Ufa: Gilem, 2012,488 p.

93. Putz F. E., Coley P. D., Lu K., Montalvo A., Aiello A. Uprooting and snapping of trees: structural determinants and ecological consequences. Canadian Journal of Forest Research. 1983, vol. 13, pp. 1011-1020.

94. Aleinikov A. A., Bovkunov A. D. Micromosaic organization of large-filical and high-grass fir-spruce forests of the Pechora-Ilych reserve. Proceedings of Penza State Pedagogical University named after V.G. Belinsky. Natural sciences. 2011, no. 25, pp. 38-43.

95. Goncharov A. A., Khramov E. Y., Tiunov A. V. Micro-habitat differences of trophic structure of soil invertebrate communities in forests of the Pechora-Ilych reserve. Pedology. 2014, no. 5, pp. 571-579.

96. Smirnova O.V., Bobrovskii M. V. Tree ontogenesis and its reflection in the structure and dynamics of vegetation and soil covers. Ecology. 2001, no. 3, pp. 177-181.

97. Smirnova O. V. Methodological approaches and methods of assessment of the climax and succession condition of forest ecosystems (by the example of Eastern European forests). Dendrology. 2004, no. 3, pp. 15-27.

98. Sukachev V. N. Selected works. Leningrad: Science, 1975, vol. 3, Problems of phytocenology, 543 p.

99. Mirkin B. M., Rozenberg G. S., Naumova L. G. Dictionary of notions and terms of modern phytocenology. Moscow: Science, 1989, 223 p.

100. Raymers N. F. Nature management: reference-dictionary. Moscow: Idea, 1990, 637 p.

101. Davidson A. D., Lightfoot D. C. Keystone rodent interactions: prairie dogs and kangaroo rats structure the biotic composition of a desertified grassland. Ecography. 2006, vol. 29, pp. 755-765.

102. Fischer J., Lindenmayer D. B., Manning A. D. Biodiversity, ecosystem function, and resilience: ten guiding principles for commodity production landscapes. Front Ecol. Environ. 2006, vol. 4 (2), pp. 80-86.

103. Fischer J., Lindenmayer D. B. Landscape modification and habitat fragmentation: a synthesis. Global Ecology and Biogeography. 2007, vol. 16, pp. 265-280.

104. Cuddington K., Hastings A. Invasive engineers. Ecological Modelling. 2004, vol. 178, pp. 335-347.

105. Jouquet P., Dauber J., Lagerlof J., Lavelle P., Lepage M. Soil invertebrates as ecosystem engineers: Intended and accidental effects on soil and feedback loops. Applied Soil Ecology. 2006, vol. 32, pp. 153-164.

106. Hastings A., E. Byers J., Crooks J. A., Cuddington K., Jones C. G., Lambrinos J. G., Talley T. S., Wilson W. G. Ecosystem engineering in space and time. Ecol. Lett. 2007, vol. 10, pp. 153-164.

107. Grubb P. J. The maintenance of species richness in plant communities: The importance of the regeneration niche. Biol. Rev. 1977, vol. 52, pp. 107-145.

108. Lovelock J. E. Gaia. A new look at life on Earth. New York: Oxford Univ. Press, 1982, 157 p.

109. Levin S. A. Ecosystems and Biosphere as Complex Adaptive Systems. Ecosystems. 1998, vol. 1, pp. $431-436$.

110. Kirchner J. W. The gaia hypothesis: fact, theory, and wishful thinking. Climatic Change. 2002, vol. 52, pp. 391408.

111. Viability of populations. Aspects of nature preservation. Moscow: World, 1989, $224 \mathrm{p}$.

112. Uranov A. A., Smirnova O. V. Classification and basic elements of perennial populations development. Bulletin of MSN. Biological department. 1969, vol. 74, issue 2, pp. 119-134.

113. Smirnova O. V., Bakun E. Y., Turubanova S. A. The conception of potential and recovered plant cover of the forest belt of Eastern Europe. Dendrology. 2006, no. 1, pp. 22-33.

114. Harper J. L. Population biology of plants. New York: Acad. Press, 1977, 892 p.

115. Pererva V. I., Pererva A. V. Modern condition and prospects of formation of a free population of aurochs in the "Kaluzhskie zaseki" reserve. Proceedings of the "Kaluzhskie zaseki» reserve. Kaluga, 2003, issue 1, pp. $203-220$.

116. Zablotskaya M. M., Pererva A. V. Modern problems of aurochs restoration in Russia. Problems of aurochs preservation and restoration: collected papers. Danki, 2004, pp. 43-47.

117. Sipko T. P. Modern problems of aurochs restoration. Problems of aurochs preservation and restoration: collected papers. Danki, 2004, pp. 12-18.

118. Belousova I. P., Smirnov K. A., Kudryavtsev I. V., Kazmin V. D. Reintroduction of European aurochs into the forest ecosystem of the "Orlovskoe Polesye" national park Ecology. 2005, no. 2, pp. 132-137.

119. Yoccoz N. G., Stenseth N. C. Population ecology and conservation of endangered megafauna: the case of European bison in Białowiez'a Primeval Forest, Poland. Animal conservation. 2007, vol. 10, pp. 77-87.

120. Kozlo P. G., Bunevich A. N. Aurochs in Belarus. Minsk: Belarus science, 2011, 366 p.

121. Zavyalov N. A. Environment-forming activity of beavers: new works and hypotheses. Research of beavers in Eurasia: collected papers Edited by A. P. Savelyev; ARRIIA named after prof. B. M. Zhitkov of RAAS. Kirov: Alpha-Com, 2011, issue 1, pp. 41-52.

122. Zavyalov N. A. Ecological features of beavers (Castor fiber), occupying watersheds and initial links of drainage. Zoological journal. 2012, vol. 91, no. 4, pp. 464-474.

123. Chumachenko S. I., Smirnova O. V. Plantation succession dynamics modeling. Dendrology. 2009, no. 6, pp. 3-17. 
124. Smirnova O. V., Chistyakova A. A., Popadyuk R. V., Evstigneev O. I., Korotkov V. N., Mitrofanova M. V., Ponomarenko E. V. Population organization of plant cover of forest areas (by the example of broad-leaved forests of the European part of USSR). Pushchino: Joint Institute of Science and Technology, Research Center of Biological Research of AS USSR, 1990, $92 \mathrm{p}$.

125. Succession processes in Russian reserves and problems of biological diversity preservation. Edited by O. V. Smirnova, E. S. Shaposhnikov. Saint-Petersburg: ZRBO, 1999, 549 p.

126. Estimation and preservation of forest cover biodiversity in reserves of European Russia. Edited by L. B. Zaugolnova, T. Y. Braslavskaya. Moscow: Scientific world, 2000, 185 p.

127. Smirnova O. V., Lugovaya D. V., Prokazina T. S. Model Reconstruction of Restored Taiga Forest Cover. Uspekhi Sovremennoi Biologii [Biology Bulletin Reviews ]. 2013, vol. 3, no. 6, pp. 493-504.

128. Smirnova O. V., Popadyuk R. V., Zaugolnova L. B., Khanina L. G. Estimation of floristic diversity losses in forest vegetation (by the example of the "Kaluzhskie zaseki" reserve). Dendrology. 1997, no. 2, pp. $27-42$.

129. Smirnova O. V., Shevchenko N. E., Smirnov N. S. Estimation of floristic diversity losses in basic types of dark coniferous forests in the upper Pechora river. Proceedings of the Pechora-Ilych reserve. Syktyvkar, 2015, issue 17, pp. 147-153.

130. Pashchenko A. I. On the issue of studying the plant cover dynamics of fallows of the Stony steppe. Natural resources of Voronezh region and protection thereof. Voronezh, 1992, pp. 4-13.

131. Chibilyov A. A. Steppes of Northern Eurasia: an ecological-geographic essay and bibliography. Ekaterinburg, 1998, $100 \mathrm{p}$.

132. Parnikoza I. Y. Actual situation of modern haymaking in steppe reserves of Ukraine and biodiversity protection. Steppe bulletin. 2014, no. 40, pp. 16-21.

133. Sokolov V. E., Filonov K. P., Nukhimovskaya Y. D., Shadrina G. D. Ecology of protected areas. Edited by V. E. Sokolov, V. N. Tikhomirov. Moscow: Yanus-K, 1997, 574 p.

134. Toropova N. A., Smirnova O. V. Ecological risk of turning areas into reserves and ways of its overcoming: a review of modern conceptions. Bulletin of TSU. 2014, vol. 19, issue 5, pp. 1577-1580.

\section{Cnucoк лumepamypы}

1. Gamfeldt, L. Multiple functions increase the importance of biodiversity for overall ecosystem functioning / L. Gamfeldt, H. Hillebrand, P. R. Jonsson // Ecology. - 2008. - Vol. 89 (5). - P. 1223-1231.

2. Ecosystem and biodiversity economics: potential and prospects of Northern Eurasian countries: proceedings of the conference «Project TEEB - ecosystem and biodiversity economics: participation prospects of Russia and other members of NIS». - M., 2010. - 136 pp.

3. Pavlov, D. S. Climate-regulating functions of ground ecosystems and the ecology-focused conception of nature management / D. S. Pavlov, E. N. Bukvareva // Progress of modern biology. - 2011. - Vol. 131, № 4. - pp. 324-345.

4. Tuxen, R. Modern potential of natural vegetation as an object for plant cover mapping / R. Tuxen // Applied plant sociology (Stolzenau). - 1956. - Vol. 13. - P. 4-42.

5. Clements, F. E. Nature and structure of the climax / F. E. Clements // Journal of Ecology. - 1936. - Vol. 24. P. 254-282.

6. Westhoff, V. The Braun-Blanquet approach / V. Westhoff, E. van der Maarel // Handbook of Vegetation Science. V. Ordination and classification of communities / ed. by R. H. Whittaker. - The Hague, 1973. - P. 617-726.

7. Brzeziecki, B. A simulation map of the potential natural forest vegetation of Switzerland / B. Brzeziecki, F. Kienast, O. Wildi // J. Veget. Sci. - 1993. - Vol. 4. - № 2. - P. 149-156.

8. Stumpel, A. H. P. A vegetation map of the Netherland, based on the relationship between ecotypes and types of potentional natural vegetation / A. H. P. Stumpel, J. T. R. Kalkhove // Vegetatio. - 1978. - Vol. 37. - P. 11671179.

9. Chytry, M. Potential replacement vegetation: An approach to vegetation mapping of cultural landscapes / M. Chytry // Applied Vegetation Science. - 1998. - Vol. 1. - P. 177-188.

10. Are potential natural vegetation maps a meaningful alternative to neutral landscape models? / C. Ricotta, M. L. Carranza, G. Avena, C. Blasi // Applied Vegetation Science. - 2002. - Vol. 5. - P. 271-275.

11. Kelly, A. Predicting Potential Natural Vegetation in an Interior Northwest Landscape Using Classification Tree Modeling and a GIS / A. Kelly, D. C. Powell, R. A. Riggs // Western Journal of Applied Forestry. - 2005. Vol. 20. - № 2. - P. 117-127.

12. Hall, M. J. G. Potential forest cover of New Zealand as determined by ecosystem process model / M. J. Graeme Hall, S. Matt McGlone // New Zealand Journal of Botany. - 2006. - Vol. 44. - P. 211-232.

13. Leuschner, C. The concept of a potential natural vegetation (PNV): problems and suggested improvements / C. Leuschner // Flora. - 1997. - Vol. 1. - P. 431-436.

14. Brunet, J. Biodiversity in European beech forests - a review with recommendations for sustainable forest management / J. Brunet, O. Fritz, G. Richnau // Ecological Bulletins. - 2010. - Vol. 53. - P. 77-94.

15. Oak (Quercus robur L.) regeneration in early successional woodlands grazed by wild ungulates in the absence of livestock / A. Bobiec, D. P. J. Kuijper, M. Niklasson, A. Romankiewicz, K. Solecka // Forest ecology and management. - 2011. - Vol. 262. - P. 780-790. 
16. Projecting the future distribution of European potential natural vegetation zones with a generalized, tree speciesbased dynamic vegetation model / T. Hickler, K. Vohland, J. Feehan, P. A. Miller, B. Smith, L. Costa, T. Giesecke, S. Fronzek, T. R. Carter, W. Cramer, I. Kühn, M. T. Sykes // Global Ecology and Biogeography. 2012. - Vol. 21. - P. 50-63.

17. Connell, J. H. Mechanisms of succession in natural communities and their role in community stability and organization / J. H. Connell, R. O. Slatyer // The American Naturalist. - 1977. - Vol. 111. - № 982. - P. $1119-1144$.

18. Stone, L. Chaos, cycles and spatiotemporal dynamics in plant ecology / L. Stone, S. Ezrati // Journal of Ecology. 1996. - Vol. 84. - P. 279-291.

19. Pickett, S. T. A. Ever since Clements: from succession to vegetation dynamics and understanding to intervention / S. T. A. Pickett, M. L. Cadenasso, S. J. Meiners // Applied Vegetation Science. - 2008. - Vol. 12. - P. 9-21.

20. Vera, F. W. M. Grazing ecology and forest history / F. W. M. Vera. - Oxon, New York : CABI Publishing, 2000. $506 \mathrm{p}$.

21. Quantifying landscape change with actual vs potential natural vegetation maps / M. L. Carranza, C. Ricotta, P. Fortini, C. Blasi // Phytocoenologia. - 2003. - Vol. 33. - P. 591-601.

22. Carrio'n, J. S. The survival of the "natural potential vegetation" concept (or the power of tradition) / J. S. Carrio'n, S. Fernandez // J. of Biogeography. - 2009. - Vol. 36. - P. 2202-2203.

23. Carrio'n, J. S. The concepts of potential natural vegetation (PNV) and other abstraction (trying to pick up fish with wet hands) / J. S. Carrio'n // J. of Biogeography. - 2010. - Vol. 37. - P. 2213-2215.

24. The concept of potential natural vegetation: an epitaph? / A. Chiarucci, M. B. Araujo, G. Decocq, C. Beierkuhnlein, J. M. Fernandez-Palacios // J. of Vegetation Science. - 2010. - Vol. 21. - P. 1172-1178.

25. Loidi, J. Potential natural vegetation: reburing or reboring / J. Loidi, F. Fernandez-Gonzalez // J. of Vegetation Science. - 2012. - Vol. 23. - P. 596-604.

26. Zerbe, S. Potential natural vegetation: validity and applicability in landscape planning and nature conservation / S. Zerbe // Applied Vegetation Science. - 1998. - Vol. 1. - P. 165-172.

27. Actual and potential natural vegetation on the Canary Islands and its conservation status / M. J. A. Aguilar, R. Gonzalez-Gonzalez, V. Garzon-Machado, B. Pizarro-Hernandez // Biodiversity and Conservation. - 2010. Vol. 11. - P. 3089-3140.

28. The power of potential natural vegetation (and of spatial-temporal scale): a response to Carrio'n \& Fernandez / E. Farris, G. Filibeck, M. Marignani, L. Rosati // J. of Biogeography. - 2010. - Vol. 37. - P. 2211-2213.

29. Zampieri, M. Simple statistical approach for computing land cover types and potential natural vegetation / M. Zampieri, P. Lionello // Climate Research. - 2010. - Vol. 41. - P. 205-220.

30. Vaca, R. A. Using climatically based random forests to downscale coarse-grained potential natural vegetation maps in tropical Mexico / R. A. Vaca, D. J. Golicher, L. Cayuela // Applied Vegetation Science. - 2011. - Vol. 14. P. 388-401.

31. Wang, H. Sensitivity of potential natural vegetation in China to projected changes in temperature, precipitation and atmospheric $\mathrm{CO}_{2} /$ H. Wang, J. Ni, I. C. Prentice // Regional Environmental Change. - 2011. - Vol. 11. P. 715-727.

32. Somodi, I. Toward a more transparent use of the potential natural vegetation concept - an answer to Chiarucci et al. / I. Somodi, Z. Molnar, J. Ewald // J. of Vegetation Science. - 2012. - Vol. 23. - P. 590-595.

33. McIntosh, R. P. The Myth of Community as Organism / R. P. McIntosh // Perspectives in biology and medicine. 1997. - Vol. 41, № 3. - C. 426-438.

34. Braun-Blauquet, J. Vocabulaire de sociologie vegetale / J. Braun-Blauquet, J. Pavillard. - 2nd ed. - Montpellier, 1925. $-22 \mathrm{p}$.

35. Odum, E. P. Ecology. / E. P. Odum. - New York : Holt, Rinehart and Winston, 1963. - 152 p. - (Modern Biology Series).

36. Odum, E. P. Strategy of ecosystem development / E. P. Odum // Science. - 1969. - Vol. 164. - P. $262-270$.

37. Eastern European broad-leaved forests / edited by O.V. Smirnova. - M. : Science, 1994. - 364 p.

38. Eastern European forests: history in the Holocene and modern times / edited by O. V. Smirnova. - M. : Science, 2004. - Book 1. - 479 p. ; book 2. -575 p.

39. Bobrovskii, M.V. Forest soils of European Russia: biotic and anthropogenic formation factors / M. V. Bobrovskii. M. : KMK, 2010. - 359 p.

40. Kyuster, Kh. History of forests. A view from Germany : translation from German / Kh. Kyuster. - M. : Higher school of economics, 2012. - 304 p.

41. Vera, F. W. M. Large herbivores: missing partners of western European light-demanding tree and shrub species? / F. W. M. Vera, E. Bakker, H. Olff // Large herbivore ecology, ecosystem dynamics and conservation. Biology series / ed. by K. Danell, P. Duncan, R. Bergstrom, J. Pastor. - Cambridge University Press, 2006. - P. $203-231$.

42. Historical reconstruction of the biocenotic cover of Eastern Europe and the problem of biological diversity preservation / O. V. Smirnova, S. A. Turubanova, M. V. Bobrovskii, V. N. Korotkov [and others] // Progress of modern biology. - 2001. - № 2. - pp. 144-159.

43. Genesis of the Eastern European taiga in the Holocene / O.V. Smirnova, V. N. Kalyakin, S. A. Turubanova, E. Y. Bakun // Regularities of secular dynamics of biogeocenoses. XXI reading in the memory of academician V. N. Sukachev. - M. : KMK, 2006. - pp. 18-65. 
44. The ecological history of European forest / ed. by K. Kirby, C. Watkins. - Cambridge : Cambridge University Press, 1998. $-384 \mathrm{p}$.

45. Vernadsky, V. I. The Biosphere and the Noosphere / V. I. Vernadsky // Amer. Scientist. - 1945. - Vol. 33. - P. 1-12.

46. Kuzmina, I.E. Formation of Northern Ural's theriofauna in the late Anthropogene / I. E. Kuzmina // Proceedings of Zoological Institute of AS USSR. - 1971. - Vol. 49. - pp. 44-122.

47. Vereshchagin, N.K. Formation of theriofauna of USSR in the Quaternary / N. K. Vereshchagin, I. M. Gromov // Progress of modern theriology. - M. : Science, 1977. - pp. 32-45.

48. Puchkov, P. V. Uncompensated Wurm extinctions. Message 2. Environmental transformation by giant phytophages / P. V. Puchkov // Bulletin of zoology. - 1992. - № 1. - pp. 58-66.

49. Fate of the Holarctic megafauna in the late Anthropogene / V. I. Zhegallo, N. N. Kalandadze, T. V. Kuznetsova, A. S. Rautian // The mammoth and its environment: 200 years of research. - M. : Geos, 2001. - pp. 287-306.

50. Kaluakin, V. N. On causes and consequences of the collapse of mammoth faunas / V. N. Kaluakin // Progress of modern biology. - 2014. - Vol. 134, № 1. - pp. 81-96.

51. Vegetation restoration of meadow steppes of the Central-Chernozem zone (Stony steppe) / N. I. Bobrovskaya, T. I. Kazantseva, A. I. Pashchenko, V. V. Tishchenko // Arid ecosystems. - 2000. - № 12. - pp. 150-159.

52. Species composition change of a meadow-steppe fallow in the process of its transformation into a forest group / N. I Bobrovskaya, T. I. Kazantseva, A. I. Pashchenko, V. V. Tishchenko // Steppes of Northern Eurasia: proceedings of VI International symposium - Orenburg, 2012. - pp. 105-111.

53. Vegetation dynamics of a 100-years-old steppe fallow (Stony steppe, Voronezh region) / T. I. Kazantseva, N. I. Bobrovskaya, A. I. Pashchenko, V. V. Tishchenko // Botanical journal. - 2008. - Vol. 93, № 4. - pp. 620-633.

54. Kazantseva, T. I. Features of restoration of fallow vegetation of meadow steppes of the Central Chernozem area (Voronezh region) / T. I. Kazantseva, N. I. Bobraovskaya, V. V. Tishchenko // Arid ecosystems. - 2010. Vol. 16, № 2 (42). - pp. 76-86.

55. Lysenko, G. N. Steppe reserves and the absolute reserve mode: search for a compromise / G. N. Lysenko // Steppe bulletin. - 2014. - № 40. - pp. 11-15.

56. Allen, T. F. H. Hierarchy: perspectives for ecological complexity / T. F. H. Allen, T. B. Starr. - Chicago : Univ. of Chicago Press, 1982. - 216 p.

57. A hierarchical concept of the ecosystem / R. V. O'Neill, D. L. De Anglis, J. B. Waide, T. F. H. Allen. - Princeton, New Jersey : Prinston Univ. Press, 1986. - 196 p.

58. Pickett, S. T. A. A hierarchical consideration of causes and mechanisms of succession / S. T. A. Pickett, S. L. Collins, J. J. Armesto // Vegetatio. - 1987. - Vol. 69. - P. 109-114.

59. Acker, S. A. Vegetation as a component of non-nested hierarchy: a conceptual model / S. A. Acker // J. of Vegetation Science. - 1990. - Vol. 1, № 5. - P. 683-690.

60. Collins, S. L. The hierarchical continuum concept / S. L. Collins, S. M. Glenn, D. W. Roberts // J. of Vegetation Science. - 1993. - Vol. 4, № 2. - P. 149-156.

61. Andel, J. van. A population ecological approach to evaluate the rate of disturbance of plant communities / J. van Andel // Proc. of VI Inter. Ecol. Cong. - Manchester, 1994. - P. 30-35.

62. Smirnova, O. V. The hierarchical continuum concept as a basis for analysis of succession processes and development of biodiversity preservation methods / O. V. Smirnova, L. B. Zaugolnova, R. V. Popadyuk // Succession processes in Russian nature reserves and problems of biodiversity preservation. - SPb., 1999. - pp. 14-26.

63. Watt, A. S. Pattern and Process in plant communities / A. S. Watt // Journal of Ecology - 1947. - Vol. 35. - P. 1-22.

64. Aubreville, A. Regeneration patterns in closed forest of Ivory Coast / A. Aubreville // Word vegetation types. NewYork : Columbia Univ. Press, 1971. - P. 41-55.

65. Falinski, J. B. Uprooted trees, their distribution and influence on primeval forest biotope / J. B. Falinski // Vegetatio. - 1978. - Vol. 38, № 3. - P. 175-183.

66. Brokaw, N. V. L. Species composition in gaps and structure of a tropical forest / N. V. L. Brokaw, S. M. Scheiner // Ecology. - 1989. - Vol. 70. - № 3. - P. 538-541.

67. Korotkov, V. N. A new paradigm in forest ecology / V. N. Korotkov // Biological sciences. - 1991. - № 8. - pp. 7-20.

68. Acevedo, M. F. Transition and gap models in forest dynamics / M. F. Acevedo, D. L. Urban, M. Ablan // Ecological Applications. - 1995. - Vol. 5. - P. 1040-1055.

69. McCarthy, J. Gap dynamics of forest trees: A review with particular attention to boreal forest / J. McCarthy // Environ. Rev. - 2001. - Vol. 9. - P 1-59.

70. Population ecology and conservation of endangered megafauna: the case of European bison in Białowieża Primeval Forest, Poland / A. Mysterud, K. A. Bartoń, B. Jędrzejewska, Z. A. Krasiński, M. Niedziałkowska, J. F. Kamler, N. C. Stenseth // Animal Conservation. - 2007. - Vol. 10 (1). - P. 77-87.

71. The mosaic-cycle concept of ecosystem / ed. by H. Remmert. - Berlin ; Heidelberg ; NewYork : Springer-Verlag, 1991. $-168 \mathrm{p}$.

72. Smirnova, O. V. Population organization of the biocenotic cover of forest landscapes / O. V. Smirnova // Progress of modern biology. - 1998. - № 2. - pp. 25-39.

73. Rich deciduous forests in Białowieża as a dynamic mosaic of developmental phases: premises for nature conservation and restoration management / A. Bobiec, H. Burgt, K. Meijer, C. Zuyderduyn, J. Haga, B. Vlaanderen // Forest ecology and management. -2000. - Vol. 130. - P. 159-175. 
74. McCarthy, J. W. Age and size structure of gap-dynamic, old-growth boreal forest stands in Newfoundland / J. W. McCarthy, G. Weetman // Silva Fennica. - 2006. - Vol. 40 (2). - P. 209-230.

75. The ecology of natural disturbance and patch dynamics. - Orlando : Acad. press, 1985. $-472 \mathrm{p}$.

76. Disturbance Dynamics in Boreal Forest: Defining the Ecological Basis of Restoration and Management of Biodiversity. -2002 . - Vol. 36 (1). -447 p.

77. Modelling natural disturbances in forest ecosystems: a review / R. Seidl, P. M. Fernandes, T. F. Fonseca, F. Gillet, A. M. Jönssong, K. Merganicová, S. Netherer, A. Arpaci, J.-D. Bontemps, H. Bugmann, R. J. González-Olabarria, P. Laschn, C. Meredieuo, F. Moreira, M.-J. Schelhaas, F. Mohrenr // Ecological Modelling. - 2011. - Vol. 222. P. 903-924.

78. Sukachev, V.N. Plant communities (Introduction into phytosociology) / V. N. Sukachev. - M. ; L. : Book, 1928. $58 \mathrm{p}$.

79. Hastings, A. Ecosystem engineering in space and time. Review and synthesis / A. Hastings, J. E. Byers, J. A. Crooks // Ecol. Lett. - 2008. - Vol. 10. - P.153-164.

80. Smirnova, O.V. Succession and climax as an ecosystem process / O. V. Smirnova, N. A. Toropova // Progress of modern biology. - 2008. - № 2. - pp. 129-144.

81. Rabotnov, T.A. Problems in studying a population composition for phytocenological purposes / T. A. Rabotnov // Problems of botany. - M. ; L., 1950. - issue 1. - pp. 465-483.

82. Cenopopulations of plants (basic concepts and structure). - M. : Science, 1976. - $216 \mathrm{p}$.

83. Cenopopulations of plants (development and interaction). - M. : Science, 1977. - 134 p.

84. Cenopopulations of plants (population biology essays). - M. : Science, 1988. $-184 \mathrm{p}$.

85. Age states of plants of various growth forms: a review / L. E. Gatzuk, O. V. Smirnova, L. I. Vorontzova, L. B. Zaugolnova, L. A. Zhukova // Journal of Ecology. - 1980. - Vol. 68, № 3. - P. 675-696.

86. The population structure of vegetation // Handbook of vegetation science / ed. by J. White. - Dodrecht ; Boston ; Lancaster, 1985. $-362 \mathrm{p}$.

87. Population mosaic cycles in forest ecosystems / O. V. Smirnova, L. B. Zaugolnova, I. I. Istomina, L. G. Khanina // Proceedings IAVS Symposium. - Uppsala : Opulus Press, 2000. - P. 108-112.

88. Smirnova, O.V. Population methods for determination of the minimal area of forest cenosis / O. V. Smirnova, R. V. Popuadyuk, A. A. Chistyakova // Botanical journal. - 1988. - Vol. 73, № 10. - pp. 1423-1434.

89. Smirnova, O. V. The population concept in biocenology / O. V. Smirnova, L. B. Zaugolnova, R.V. Popadyuk // Journal of general biology. - 1993. - Vol 54, № 4. - pp. 438-448.

90. Mordkovich, V.G. Steppe catenas / V. G. Mordkovich, N. G. Shatokhina, A. A. Titlyanova. - Novosibirsk : Science, 1985. - $117 \mathrm{p}$.

91. Methodological approaches to ecological assessment of a forest cover in a small river basin / edited by L. B. Zaugolnova, T. Y. Braslavskaya. - M. : KMK, 2010. - 383 p.

92. Mirkin, B. M. Modern condition of main vegetation science concepts / B. M. Mirkin, L. G. Naumova. - Ufa: Gilem, 2012. - 488 p.

93. Putz, F. E. Uprooting and snapping of trees: structural determinants and ecological consequences / F. E. Putz, P. D. Coley, K. Lu, A. Montalvo, A. Aiello // Canadian Journal of Forest Research. - 1983. - Vol. 13. - P. 10111020.

94. Aleinikov, A. A. Micromosaic organization of large-filical and high-grass fir-spruce forests of the Pechora-Ilych reserve / A. A. Aleinikov, A. D. Bovkunov // Proceedings of Penza State Pedagogical University named after V. G. Belinsky. Natural sciences. - 2011. - № 25. - pp. 38-43.

95. Goncharov, A. A. Micro-habitat differences of trophic structure of soil invertebrate communities in forests of the Pechora-Ilych reserve / A. A Goncharov, E. Y. Khramov, A. V. Tiunov // Pedology. - 2014. - № 5. - pp. 571579.

96. Smirnova, O.V. Tree ontogenesis and its reflection in the structure and dynamics of vegetation and soil covers / O. V. Smirnova, M. V. Bobrovskii // Ecology. - 2001. - № 3. - pp. 177-181.

97. Smirnova, O.V. Methodological approaches and methods of assessment of the climax and succession condition of forest ecosystems (by the example of Eastern European forests) / O. V. Smirnova // Dendrology. - 2004. - № 3. pp. 15-27.

98. Sukachev, V. N. Selected works / V. N. Sukachev. - L. : Science, 1975. - Vol. 3. Problems of phytocenology. $543 \mathrm{p}$.

99. Mirkin, B.M. Dictionary of notions and terms of modern phytocenology / B. M. Mirkin, G. S. Rozenberg, L. G. Naumova. - Moscow : Science, 1989. - 223 p.

100. Raymers, N. F. Nature management: reference-dictionary / N. F. Raymers. - M. : Idea, 1990. -637 p.

101. Davidson, A. D. Keystone rodent interactions: prairie dogs and kangaroo rats structure the biotic composition of a desertified grassland / A. D. Davidson, D. C. Lightfoot // Ecography. - 2006. - Vol. 29. - P. $755-765$.

102. Fischer, J. Biodiversity, ecosystem function, and resilience: ten guiding principles for commodity production landscapes / J. Fischer, D. B. Lindenmayer, A. D. Manning // Front Ecol. Environ. - 2006. - Vol. 4 (2). - P. 80-86.

103. Fischer, J. Landscape modification and habitat fragmentation: a synthesis / J. Fischer, D. B. Lindenmayer // Global Ecology and Biogeography. - 2007. - Vol. 16. - P. 265-280.

104. Cuddington, K. Invasive engineers / K. Cuddington, A. Hastings // Ecological Modelling. - 2004. - Vol. 178. P. 335-347. 
105. Soil invertebrates as ecosystem engineers: Intended and accidental effects on soil and feedback loops / P. Jouquet, J. Dauber, J. Lagerlof, P. Lavelle, M. Lepage // Applied Soil Ecology. - 2006. - Vol. 32. - P. 153-164.

106. Ecosystem engineering in space and time / A. Hastings, J. E. Byers, J. A. Crooks, K. Cuddington, C. G. Jones, J. G. Lambrinos, T. S. Talley, W. G. Wilson // Ecol. Lett. - 2007. - Vol. 10. - P. 153-164.

107. Grubb, P. J. The maintenance of species richness in plant communities: The importance of the regeneration niche $/$ P. J. Grubb // Biol. Rev. - 1977. - Vol. 52. - P. 107-145.

108. Lovelock, J. E. Gaia. A new look at life on Earth / J. E. Lovelock. - New York : Oxford Univ. Press, $1982 .-157$ p.

109. Levin, S. A. Ecosystems and Biosphere as Complex Adaptive Systems / S. A. Levin // Ecosystems. - 1998. Vol. 1 - P. 431-436.

110. Kirchner, J. W. The gaia hypothesis: fact, theory, and wishful thinking / J. W. Kirchner // Climatic Change. 2002. - Vol. 52. - P. 391-408.

111. Viability of populations. Aspects of nature preservation. - M. : World, 1989. - 224 p.

112. Uranov, A. A. Classification and basic elements of perennial populations development / A. A. Uranov, O. V. Smirnova // Bulletin of MSN. Biological department - 1969. - Vol. 74, issue. 2. - pp. 119-134.

113. Smirnova, O. V. The conception of potential and recovered plant cover of the forest belt of Eastern Europe / O. V. Smirnova, E. Y. Bakun, S. A. Turubanova // Dendrology. - 2006. - № 1. - pp. 22-33.

114. Harper, J. L. Population biology of plants / J. L. Harper. - New York : Acad. Press, 1977. - 892 p.

115. Pererva, V. I. Modern condition and prospects of formation of a free population of aurochs in the "Kaluzhskie zaseki" reserve / V. I. Pererva, A. V. Pererva // Proceedings of the «Kaluzhskie zaseki» reserve. - Kaluga, 2003. Issue 1. - pp. 203-220.

116. Zablotskaya, M. M. Modern problems of aurochs restoration in Russia / V. I. Pererva, A. V. Pererva // Problems of aurochs preservation and restoration : collected papers - Danki, 2004. - pp. 43-47.

117. Sipko, T. P. Modern problems of aurochs restoration / T. P. Sipko // Problems of aurochs preservation and restoration : collected papers - Danki, 2004. - pp. 12-18.

118. Reintroduction of European aurochs into the forest ecosystem of the "Orlovskoe Polesye" national park / I. P. Belousova, K. A. Smirnov, I. V. Kudryavtsev, V. D. Kazmin // Ecology. - 2005. - № 2. - pp. 132-137.

119. Yoccoz, N. G. Population ecology and conservation of endangered megafauna: the case of European bison in Białowiez'a Primeval Forest, Poland / N. G. Yoccoz, N. C. Stenseth // Animal conservation. - 2007. - Vol. 10. P. 77-87.

120. Kozlo, P. G. Aurochs in Belarus / P. G. Kozlo, A. N. Bunevich. - Minsk : Belarus science, 2011. - 366 p.

121. Zavyalov, N. A. Environment-forming activity of beavers: new works and hypotheses / N. A. Zavyalov // Research of beavers in Eurasia : collected papers / edited by A. P. Savelyev ; ARRIIA named after prof. B. M. Zhitkov of RAAS. - Kirov : Alpha-Com, 2011. - Issue. 1. - pp. 41-52.

122. Zavyalov, N. A. Ecological features of beavers (Castor fiber), occupying watersheds and initial links of drainage / N. A. Zavyalov // Zoological journal. - 2012. - Vol. 91, № 4. - pp. 464-474.

123. Chumachenko, S. I. Plantation succession dynamics modeling / S. I. Chumachenko, O. V. Smirnova // Dendrology. 2009. - № 6. - pp. 3-17.

124. Population organization of plant cover of forest areas (by the example of broad-leaved forests of the European part of USSR) / O. V. Smirnova, A. A. Chistyakova, R. V. Popadyuk, O. I. Evstigneev, V. N. Korotkov, M. V. Mitrofanova, E. V. Ponomarenko. - Pushchino : Joint Institute of Science and Technology, Research Center of Biological Research of AS USSR, 1990. - 92 p.

125. Succession processes in Russian reserves and problems of biological diversity preservation / edited by O. V. Smirnova, E. S. Shaposhnikov. - SPb. : ZRBO, 1999. - 549 p.

126. Estimation and preservation of forest cover biodiversity in reserves of European Russia / edited by L. B. Zaugolnova, T. Y. Braslavskaya. - M. : Scientific world, 2000. - 185 p.

127. Smirnova, O. V. Model Reconstruction of Restored Taiga Forest Cover / O. V. Smirnova, D. V. Lugovaya, T. S. Prokazina // Uspekhi Sovremennoi Biologii. - 2013. - Vol. 3. - № 6. - P. 493-504.

128. Estimation of floristic diversity losses in forest vegetation (by the example of the "Kaluzhskie zaseki" reserve) / O. V. Smirnova, R. V. Popadyuk, L. B. Zaugolnova, L. G. Khanina // Dendrology. - 1997. - № 2. - pp. $27-42$.

129. Smirnova, O. V. Estimation of floristic diversity losses in basic types of dark coniferous forests in the upper Pechora river / O. V. Smirnova, N. E. Shevchenko, N. S. Smirnov // Proceedings of the Pechora-Ilych reserve. - Syktyvkar, 2015. - Issue. 17. - pp. 147-153.

130. Pashchenko, A. I. On the issue of studying the plant cover dynamics of fallows of the Stony steppe / A. I. Pashchenko // Natural resources of Voronezh region and protection thereof. - Voronezh, 1992. - pp. 4-13.

131. Chibilyov, A. A. Steppes of Northern Eurasia: an ecological-geographic essay and bibliography / A. A. Chibilyov. Ekaterinburg, 1998. - $100 \mathrm{p}$.

132. Parnikoza, I. Y. Actual situation of modern haymaking in steppe reserves of Ukraine and biodiversity protection / I. Y. Parnikoza // Steppe bulletin. - 2014. - № 40. - pp. 16-21.

133. Ecology of protected areas / V. E. Sokolov, K. P. Filonov, Y. D. Nukhimovskaya, G. D. Shadrina ; edited by V. E. Sokolov, V. N. Tikhomirov. - M. : Yanus-K, 1997. - 574 p.

134. Toropova, N.A. Ecological risk of turning areas into reserves and ways of its overcoming: a review of modern conceptions / N. A. Toropova, O. V. Smirnova // Bulletin of TSU. - 2014. - Vol. 19, issue. 5. - pp. 1577-1580. 